\title{
Photochemical Generation of Benzyl Cations That Selectively Cross-Link Guanine and Cytosine in DNA
}

Yibin Wang, ${ }^{\text {a }}$ Shuo Liu, ${ }^{\mathrm{b}}$ Zechao Lin, ${ }^{\mathrm{a}}$ Yukai Fan, ${ }^{\mathrm{a}}$ Yinsheng Wang, ${ }^{\mathrm{b}}$ and Xiaohua Peng*,a

${ }^{a}$ Department of Chemistry and Biochemistry and Milwaukee Institute of Drug Discovery, University of Wisconsin Milwaukee, 3210 North Cramer Street, Milwaukee, Wisconsin 53211, United States

${ }^{b}$ Department of Chemistry, University of California Riverside, 501 Big Springs Road, Riverside, California 92521-0403, United States

Contents:

1. Experimental procedures

2. Scheme S1. Synthesis of $4 \mathbf{a}$ and $\mathbf{4 b}$.

3. Figure S1-10 and S13-20. Phosphorimage Autoradiograms.

4. Figure S11-12. UV absorbance spectra.

5. Figure S21. Effect of TEMPO and methoxyamine on DNA ICL formation. (S13)

6. Figure S22-23. NMR analysis.

7. Figure S24-25. Determination of cross-linking site.

8. Figure S26-28. Cross-linking formation with DNA duplex 9, 10, 15, and 16. (S17-18)

9. Scheme S2. Radical trapping reactions with TEMPO.

10. Scheme S3-4. Proposed mechanism for ICL formation.

11. Figure S29. LC-MS/MS analysis of ICL product.

12. Scheme S5. LC-MS/MS analysis of ICL product.

13. Figure S30. ${ }^{1} \mathrm{H}$ NMR analysis of hydrolysis of $\mathbf{4 b}$.

14. Figure S31-39. ${ }^{1} \mathrm{H}$ NMR, ${ }^{13} \mathrm{C}$ NMR, and HRMS Spectra of compounds.

General Methods. Unless otherwise specified, chemicals were purchased from Aldrich or Fisher Scientific and were used as received without further purification. T4 polynucleotide kinase was obtained from New England Biolabs. Oligonucleotides were synthesized via standard automated DNA synthesis techniques using an Applied Biosystems model 394 instrument in a $1.0 \mu \mathrm{M}$ scale using commercial $1000 \AA$ CPGsuccinyl-nucleoside supports. Deprotection of the nucleobases and phosphate moieties as well as cleavage of the linker were carried out under mild deprotection conditions using a mixture of $40 \%$ aq. $\mathrm{MeNH}_{2}$ and $28 \%$ aq. $\mathrm{NH}_{3}$ (1:1) at room temperature for $2 \mathrm{~h}$. Radiolabeling was carried out according to the standard protocols. ${ }^{1}\left[\gamma-{ }^{32} \mathrm{P}\right] \mathrm{ATP}$ was 
purchased from Perkin-Elmer Life Sciences. Quantification of radiolabeled oligonucleotides was carried out using a Molecular Dynamics Phosphorimager equipped with ImageQuant Version 5.2 software. ${ }^{1} \mathrm{H}$ NMR and ${ }^{13} \mathrm{C}$ NMR spectra were taken on a Bruker DRX $300 \mathrm{MHz}$ spectrophotometer. High resolution masss pectrometry was performed at the University of California Riverside and Shimadzu Laboratory for Advanced \& Applied Analytical Chemistry at the University of Wisconsin Milwaukee.

Interstrand cross-link formation with duplex DNA 7 upon UV irradiation. The ${ }^{32} \mathrm{P}$ labelled oligonucleotide $(0.5 \mu \mathrm{M})$ was annealed with 1.5 equiv. of the complementary strand by heating to $65^{\circ} \mathrm{C}$ for $3 \mathrm{~min}$ in a buffer containing $10 \mathrm{mM}$ potassium phosphate (pH 7), and $100 \mathrm{mM} \mathrm{NaCl}$, followed by slow-cooling to room temperature overnight. The ${ }^{32} \mathrm{P}$-labeled oligonucleotide duplex $(2 \mu \mathrm{L}, 0.5 \mu \mathrm{M})$ was mixed with $1 \mathrm{M} \mathrm{NaCl}(2 \mu \mathrm{L}), 100$ $\mathrm{mM}$ potassium phosphate ( $2 \mu \mathrm{L}, \mathrm{pH}$ range 5-9) and different concentrations of compound 3a,b or 4a,b (concentration range: $20 \mu \mathrm{M}$ to $5 \mathrm{mM}$ in $6 \mu \mathrm{L} \mathrm{H}_{2} \mathrm{O}$ or $\mathrm{CH}_{3} \mathrm{CN}$ ) and the appropriate amount of autoclaved water or $\mathrm{CH}_{3} \mathrm{CN}$ to give a final volume of $20 \mu \mathrm{L}(6 \mu \mathrm{L}$ $\mathrm{CH}_{3} \mathrm{CN}$ with $14 \mu \mathrm{L} \mathrm{H} \mathrm{H}_{2} \mathrm{O}$ ). The reaction was irradiated with $350 \mathrm{~nm} \mathrm{UV}$ light for 1-24 hours and quenched by an equal volume of $90 \%$ formamide loading buffer, then subjected to $20 \%$ denaturing polyacrylamide gel electrophoresis (note: all cross-linking reactions were carried out under aerobic conditions).

Trapping assay of oligonucleotides. The ${ }^{32} \mathrm{P}$-labeled oligonucleotide duplex $(2 \mu \mathrm{L}, 0.5$ $\mu \mathrm{M})$ was mixed with $1 \mathrm{M} \mathrm{NaCl}(2 \mu \mathrm{L}), 100 \mathrm{mM}$ potassium phosphate $(2 \mu \mathrm{L}, \mathrm{pH} 8)$. The stock solution of $\mathrm{MeONH}_{2} \cdot \mathrm{HCl}(2 \mathrm{M})$ was titrated with $5 \mathrm{M} \mathrm{NaOH}$ to adjust the $\mathrm{pH}$ to 7.0, which was diluted to the desired concentration (10 $\mathrm{mM}$ to $1 \mathrm{M}$ ). Then, $2 \mu \mathrm{L}$ was added to the reaction mixture as appropriate for the desired concentration (final $\mathrm{MeONH}_{2}$ concentration: $1.0 \mathrm{mM}$ to $100 \mathrm{mM}$ ). Similarly, $2 \mu \mathrm{L}$ of TEMPO or BME in $\mathrm{CH}_{3} \mathrm{CN}$ (10 $\mathrm{mM}$ to $1.0 \mathrm{M}$ ) was added to the reaction mixture as appropriate for the desired concentration (final TEMPO or BME concentration: $1.0 \mathrm{mM}$ to $100 \mathrm{mM}$ ). Different concentrations of compounds $\mathbf{3 a}, \mathbf{b}$ or $\mathbf{4 a}, \mathbf{b}\left(4 \mu \mathrm{L}\right.$ in $\mathrm{H}_{2} \mathrm{O}$ or $\left.\mathrm{CH}_{3} \mathrm{CN}\right)$ and the appropriate amount of autoclaved water and $\mathrm{CH}_{3} \mathrm{CN}$ were added to give a final volume of $20 \mu \mathrm{L}$ (final: $6 \mu \mathrm{L} \mathrm{CH}_{3} \mathrm{CN}$ and $14 \mu \mathrm{L} \mathrm{H}_{2} \mathrm{O}$ ). The reaction was irradiated with $350 \mathrm{~nm}$ light for 8 
$\mathrm{h}(\mathbf{4 a}$ and $\mathbf{4 b})$ or $24 \mathrm{~h}(\mathbf{3 a}$ and $\mathbf{3 b})$ and quenched by an equal volume of $90 \%$ formamide loading buffer, then subjected to $20 \%$ denaturing polyacrylamide gel electrophoresis.

Stability study of ICL products formed with 8 . The ${ }^{32} \mathrm{P}$-labeled oligonucleotide duplex $(100 \mu \mathrm{L}, 0.5 \mu \mathrm{M})$ was mixed with $1 \mathrm{M} \mathrm{NaCl}(20 \mu \mathrm{L}), 100 \mathrm{mM}$ potassium phosphate (20 $\mu \mathrm{L}, \mathrm{pH} 8)$ and $35 \mathrm{mM} \mathrm{3a,b}$ or $4 \mathbf{a}, \mathbf{b}\left(60 \mu \mathrm{L}\right.$ in $\mathrm{H}_{2} \mathrm{O}$ or $\left.\mathrm{CH}_{3} \mathrm{CN}\right)$. The solution was irradiated with $350 \mathrm{~nm}$ UV light for $8 \mathrm{~h}$ (4a and $\mathbf{4 b}$ ) or $24 \mathrm{~h}$ (3a and $\mathbf{3 b}$ ). After the crosslinking reaction, the ICL products and monoalkylated ODNs were purified by gel electrophoresis. The isolated DNA fragments were dissolved in $\mathrm{H}_{2} \mathrm{O}(30 \mu \mathrm{L})$ and divided into three portions. One portion $(10 \mu \mathrm{L})$ was incubated with piperidine $(2 \mathrm{M}, 10 \mu \mathrm{L})$ at 90 ${ }^{\circ} \mathrm{C}$ for $30 \mathrm{~min}$, and second portion $(10 \mu \mathrm{L})$ was incubated with $0.1 \mathrm{M} \mathrm{NaCl}$ and $10 \mathrm{mM}$ potassium phosphate buffer $(\mathrm{pH} 7,10 \mu \mathrm{L})$ under the same condition, and the third portion was used as control sample. The samples were subjected to electrophoresis on a $20 \%$ denaturing polyacrylamide gel.

Hydroxyl radical reaction (Fe-EDTA reaction). Fe(II) EDTA cleavage reactions of ${ }^{32} \mathrm{P}$ labelled oligonucleotide $(0.1 \mu \mathrm{M})$ were performed in a buffer containing $50 \mu \mathrm{M}$ $\left(\mathrm{NH}_{4}\right)_{2} \mathrm{Fe}\left(\mathrm{SO}_{4}\right)_{2}, 100 \mu \mathrm{M}$ EDTA, $5 \mathrm{mM}$ sodium ascorbate, $0.5 \mathrm{M} \mathrm{NaCl}, 50 \mathrm{mM}$ sodium phosphate $\left(\mathrm{pH} 7.2\right.$ ) and $1 \mathrm{mM} \mathrm{H}_{2} \mathrm{O}_{2}$ for $3 \mathrm{~min}$ at room temperature (total substrate volume $20 \mu \mathrm{L}$ ), then quenched with $100 \mathrm{mM}$ thiourea $(10 \mu \mathrm{L})$. Samples were lyophilized, and incubated with $1 \mathrm{M}$ piperidine $(20 \mu \mathrm{L})$ at $90{ }^{\circ} \mathrm{C}$ for $30 \mathrm{~min}$. The mixture was lyophilized again, dissolved in $20 \mu \mathrm{L} \mathrm{H}_{2} \mathrm{O}: 90 \%$ formamide loading buffer (1:1) and subjected to $20 \%$ denaturing PAGE analysis.

Trapping assay with monomers. General Procedure. A solution of $\mathbf{4 a}(43 \mathrm{mg}, 0.01$ mmol) and TEMPO (156.3 mg, $1.0 \mathrm{mmol})$ in $\mathrm{CH}_{3} \mathrm{CN}(2.5 \mathrm{~mL})$ was irradiated with 350 $\mathrm{nm}$ light. After 5 days, the solvent was evaporated and the residue was purified through column chromatography with EtOAc and dichloromethane in hexane (1:2:30) to provide radical trapping adduct $\mathbf{8}(18 \mathrm{mg}, 36 \%)$ as a white solid. 
1-((3-(Bromomethyl)-5-methoxy-2-(4,4,5,5-tetramethyl-1,3,2-dioxaborolan-2-

yl)benzyl)oxy)-2,2,6,6-tetramethylpiperidine (8). ${ }^{1} \mathrm{H} \mathrm{NMR}\left(300 \mathrm{MHz}, \mathrm{CDCl}_{3}\right): \delta 7.20$

$(\mathrm{d}, J=1.2 \mathrm{~Hz}, 1 \mathrm{H}), 6.78(\mathrm{~d}, J=1.2 \mathrm{~Hz}, \mathrm{H}), 5.01$ (s, 2H), $4.77(\mathrm{~s}, 2 \mathrm{H}), 3.83(\mathrm{~s}, 3 \mathrm{H}), 1.47$

$(\mathrm{m}, 4 \mathrm{H}), 1.39(\mathrm{~s}, 12 \mathrm{H}), 1.18(\mathrm{~s}, 12 \mathrm{H}) .{ }^{13} \mathrm{C} \mathrm{NMR}\left(125 \mathrm{MHz}, \mathrm{CDCl}_{3}\right): \delta 160.9,147.7$, $144.8,114.0,112.4,83.9,60.0,55.2,39.9,34.7,33.3,25.2,20.6,17.3$. IT-TOF-MS (ESI): $\mathrm{m} / \mathrm{z}$ calcd. For $\mathrm{C}_{24} \mathrm{H}_{39} \mathrm{NO}_{4} \mathrm{BBr}[\mathrm{M}+\mathrm{H}]^{+}$496.2233, found 496.2210.

Structure elucidation by LC-MS/MS. The purified duplex DNA with ICL formed from 4b (50 pmol) was incubated in a solution containing nuclease P1 (0.5 unit), phosphodiesterase 2 (0.005 unit), $1 \mathrm{mM}$ EHNA, $30 \mathrm{mM}$ sodium acetate, and $1.0 \mathrm{mM}$ zinc acetate $(\mathrm{pH}$ 5.6) at room temperature for $48 \mathrm{~h}$. Phosphatase (0.5 unit) and phosphodiesterase 1 (0.001 unit) in a $50 \mathrm{mM}$ Tris-HCl buffer ( $\mathrm{pH}$ 8.9) were subsequently added, and the mixture was incubated at $37^{\circ} \mathrm{C}$ for $2 \mathrm{~h}$. The enzymes were then removed by chloroform extraction, and the digestion mixture was subjected to liquid chromatography-tandem mass spectrometry (LC-MS/MS) analysis. The separation was conducted on a $0.5 \times 250 \mathrm{~mm}$ Zorbax SB-C18 column $(5 \mu \mathrm{m}$ in particle size, Agilent Technologies) with an Agilent 1200 capillary HPLC pump (Agilent Technologies, Santa Clara, CA). A solution of $0.1 \%(\mathrm{v} / \mathrm{v})$ formic acid in water (solution A) and a solution of $0.1 \%(\mathrm{v} / \mathrm{v})$ formic acid in methanol (solution B) were employed as mobile phase at a flow rate of $8.0 \mu \mathrm{L} / \mathrm{min}$. A gradient of $5 \min 0-20 \% \mathrm{~B}$ and $25 \min 20-70 \% \mathrm{~B}$ were used for separation. An LTQ linear ion-trap mass spectrometer was set up for monitoring the fragmentation of the $[\mathrm{M}+\mathrm{H}]^{+}$ions of putative cross-linked dinucleoside remnants.

Scheme S1. Synthesis of $\mathbf{4 a}$ and $\mathbf{4 b}$

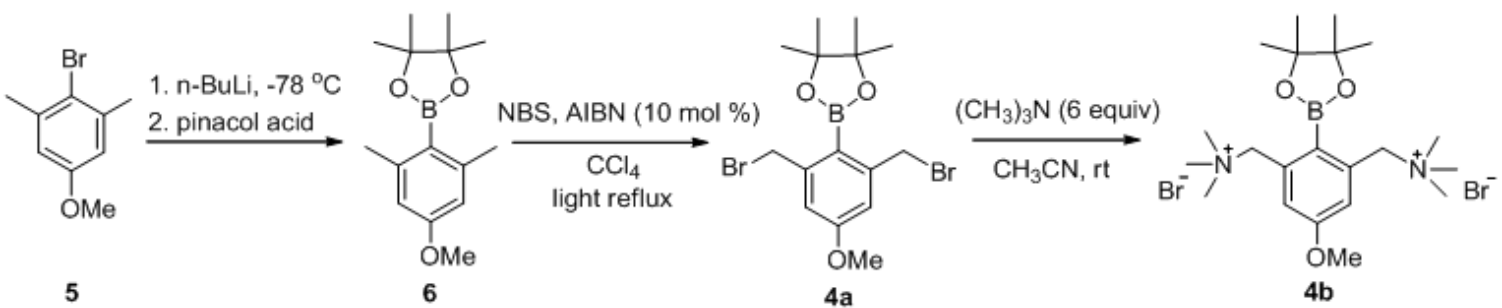

2-(4-Methoxy-2,6-dimethylphenyl)-4,4,5,5-tetramethyl-1,3,2-dioxaborolane (6). To a stirred solution of 2-bromo-5-methoxy-1,3-dimethylbenzene $(1.50 \mathrm{~g}, 7.0 \mathrm{mmol})$ in 
anhydrous THF (40 mL) was added dropwise a $2.5 \mathrm{M}$ solution of $\mathrm{n}$-BuLi (3.36 mL, 8.4 mmol) at $-78^{\circ} \mathrm{C}$ via cannula over a 2 min period under argon, and the cloudy solution was stirred at $-78{ }^{\circ} \mathrm{C}$ for $30 \mathrm{~min}$. Then, isopropoxyboronic acid pinacol ester $(1.72 \mathrm{~mL}$, $8.4 \mathrm{mmol}$ ) was added at $-78{ }^{\circ} \mathrm{C}$ under argon via syringe. The mixture was allowed to stir at $-78{ }^{\circ} \mathrm{C}$ for $30 \mathrm{~min}$, then warmed to room temperature slowly and stirred for $6 \mathrm{~h}$. The mixture was quenched with aqueous $1 \mathrm{~N} \mathrm{HCl}$ solution, extracted with 3 x $30 \mathrm{~mL}$ EtOAc, the organic layer was washed with water and brine, dried with sodium sulfate, and concentrated under reduced pressure then purified through column chromatography $(5 \%$ EtOAc/Hexane) to give $1.38 \mathrm{~g}(75 \%)$ of pure 6 as white solid. ${ }^{1} \mathrm{H}$ NMR $(300 \mathrm{MHz}$, $\left.\mathrm{CDCl}_{3}\right): \delta 6.53(\mathrm{~s}, 2 \mathrm{H}), 3.78(\mathrm{~s}, 3 \mathrm{H}), 2.42(\mathrm{~s}, 6 \mathrm{H}), 1.39(\mathrm{~s}, 12 \mathrm{H})$.

\section{2-(2,6-Bis(bromomethyl)-4-methoxyphenyl)-4,4,5,5-tetramethyl-1,3,2-dioxaborolane}

(4a). To a stirred solution of 2-(4-methoxy-2,6-dimethylphenyl)-4,4,5,5-tetramethyl1,3,2-dioxaborolane (1.31 g, $5 \mathrm{mmol})$, NBS (1.87 g, $10.5 \mathrm{mmol})$ and AIBN (82.1 mg, 0.5 mmol) in anhydrous $\mathrm{CCl}_{4}(30 \mathrm{~mL})$ was stirred to reflux under a light for $2 \mathrm{~h}$. The mixture was allowed to cool to room temperature. Evaporated the solvent and added $50 \mathrm{~mL}$ $\mathrm{CH}_{2} \mathrm{Cl}_{2}$, the organic layer was washed with water, and brine, dried with sodium sulfate, and concentrated under reduced pressure then purified through column chromatography (30\% DCM/Hexane) to give $0.63 \mathrm{~g}(30 \%)$ of $\mathbf{4 a}$ as white solid. ${ }^{1} \mathrm{H}$ NMR $(300 \mathrm{MHz}$, $\left.\mathrm{CDCl}_{3}\right): \delta 6.85(\mathrm{~s}, 2 \mathrm{H}), 4.84(\mathrm{~s}, 4 \mathrm{H}), 3.84(\mathrm{~s}, 3 \mathrm{H}), 1.46(\mathrm{~s}, 12 \mathrm{H}) .{ }^{13} \mathrm{C} \mathrm{NMR}(125 \mathrm{MHz}$, $\mathrm{CDCl}_{3}$ ): $\delta 160.7,146.4,115.7,84.0,55.3,34.1,25.1$. IT-TOF-MS (APCI): m/z calcd. for $\mathrm{C}_{15} \mathrm{H}_{21} \mathrm{O}_{3} \mathrm{BBr}_{2}[\mathrm{M}+\mathrm{H}]^{+}$419.0026, found 419.0022.

\section{1,1'-(5-Methoxy-2-(4,4,5,5-tetramethyl-1,3,2-dioxaborolan-2-yl)-1,3-}

phenylene)bis( $\mathbf{N}, \mathbf{N}, \mathbf{N}$-trimethylmethanaminium) bromide (4b). A mixture of $\mathrm{CH}_{3} \mathrm{CN}$ $(10 \mathrm{~mL}), 4.2 \mathrm{M}$ trimethylamine $(0.72 \mathrm{ml}, 3 \mathrm{mmol})$ in ethanol and 4a (419.9 mg, $1 \mathrm{mmol})$ was stirred at room temperature overnight. The reaction mixture was concentrated to give $530 \mathrm{mg}(99 \%)$ of $\mathbf{4 b}$ as white solid. ${ }^{1} \mathrm{H}$ NMR (300 MHz, DMSO- $\left.d 6\right)$ : $\delta 8.43$ (d, $J=4.2$ $\mathrm{Hz}, 2 \mathrm{H}), 7.71-7.67(\mathrm{~m}, 4 \mathrm{H}), 7.49$ (t, $J=6.9 \mathrm{~Hz}, 2 \mathrm{H}), 7.38(\mathrm{~s}, 2 \mathrm{H}), 4.83$ (s, 4H), 3.91 (s, $3 \mathrm{H}), 3.08(\mathrm{~s}, 18 \mathrm{H}), 1.40(\mathrm{~s}, 12 \mathrm{H}) .{ }^{13} \mathrm{C}$ NMR (125 MHz, DMSO-d6): $\delta$ 160.8, 136.5, 
137.5, 122.2, 85.4, 67.8, 52.9, 25.2. IT-TOF-MS(ESI): $\mathrm{m} / \mathrm{z}$ calcd. for $\mathrm{C}_{21} \mathrm{H}_{39} \mathrm{~N}_{2} \mathrm{O}_{3} \mathrm{BBr}_{2}$ $[\mathrm{M}-2 \mathrm{Br}]^{2+} 189.1523$, found 189.1522 .

\section{Reference}

1. Maniatis, T.; Fritsch, E. F.; Sambrook, J. Molecular Cloning; Cold Spring Harbor Laboratory, Cold Spring Harbor, NY., 1982.

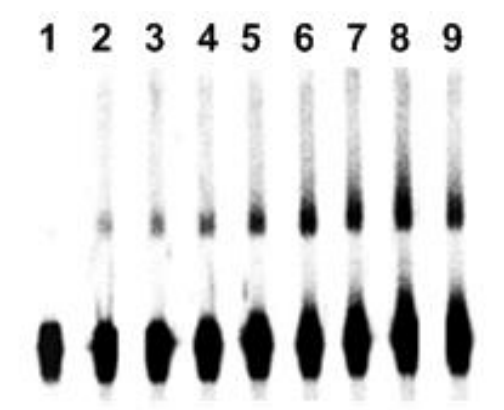

Figure S1. Representative gel of concentration dependence for DNA cross-link formation induced by 3a upon UV irradiation. Lane 1: with DNA only; lane 2: $20 \mu \mathrm{M}$ 3a (crosslinking yield 1.7\%); lane 3: $50 \mu \mathrm{M} \mathrm{3a} \mathrm{(2.6 \% );} \mathrm{lane} \mathrm{4:} 100 \mu \mathrm{M}$ 3a (3.9\%); lane 5: $200 \mu \mathrm{M}$ 3a (4.7\%); lane 6: $500 \mu \mathrm{M}$ 3a (8.5\%); lane 7: $1 \mathrm{mM}$ 3a (8.3\%); lane 8: $2 \mathrm{mM} \mathrm{3a} \mathrm{(7.5 \% );}$ lane 9: $5 \mathrm{mM}$ 3a (7.3\%). Condition: duplex 7 was irradiated by $350 \mathrm{~nm}$ light for $8 \mathrm{~h}$.

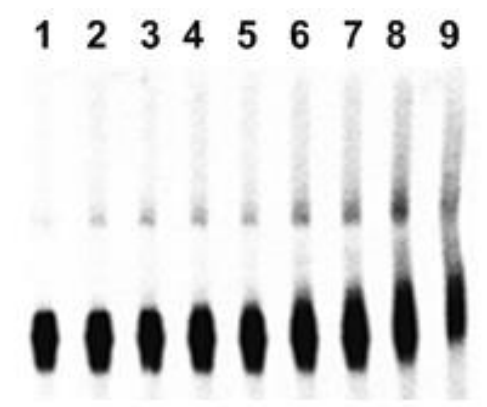

Figure S2. Representative gel of time dependence for DNA cross-link formation induced by 3a upon UV irradiation. Lane 1: no UV irradiation; lane 2: UV for 30 min (crosslinking yield 1.3\%); lane 3: $1 \mathrm{~h}(1.9 \%)$; lane $4: 2 \mathrm{~h}(2.4 \%)$; lane 5: $4 \mathrm{~h}(3.5 \%)$; lane $6: 6 \mathrm{~h}$ (5.2\%); lane 7: $8 \mathrm{~h}$ (7.3\%); lane 8: $12 \mathrm{~h}(11.8 \%)$; lane 9: $24 \mathrm{~h}$ (25.0\%). Condition: duplex 7 was irradiated by $350 \mathrm{~nm}$ light in the presence of $2 \mathrm{mM} 3 \mathbf{3 a}$. 


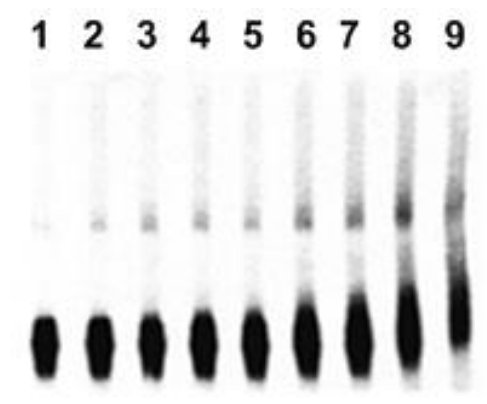

Figure S3. Representative gel of concentration dependence for DNA cross-link formation induced by $\mathbf{3 b}$ upon UV irradiation. Lane 1: with DNA only; lane 2: $20 \mu \mathrm{M}$ 3b (crosslinking yield 2.2\%); lane 3: $50 \mu \mathrm{M} 3 \mathbf{b}(3.1 \%)$; lane 4: $100 \mu \mathrm{M} 3 \mathbf{b}(3.6 \%)$; lane 5: $200 \mu \mathrm{M}$ 3b (4.0\%); lane 6: $500 \mu \mathrm{M}$ 3b (6.0\%); lane 7: $1 \mathrm{mM} \mathrm{3b}(8.5 \%)$; lane 8: $2 \mathrm{mM}$ 3b (14.0\%); lane 9: $5 \mathrm{mM}$ 3b (24.1\%). Condition: duplex 7 was irradiated by $350 \mathrm{~nm}$ light for $8 \mathrm{~h}$.

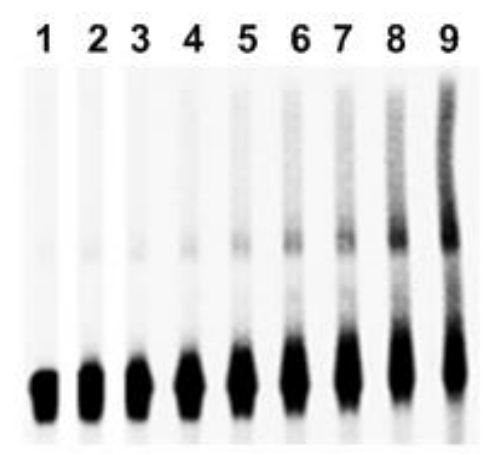

Figure S4. Representative gel of time dependence for DNA cross-link formation induced by 3b upon UV irradiation. Lane 1: no UV irradiation; lane 2: UV for $30 \mathrm{~min}$ (crosslinking yield 0.8\%); lane 3: $1 \mathrm{~h}(1.8 \%)$; lane 4: $2 \mathrm{~h} \mathrm{(3.1 \% );} \mathrm{lane} \mathrm{5:} 4 \mathrm{~h}(6.1 \%)$; lane 6: $6 \mathrm{~h}$ (10.2\%); lane 7: $8 \mathrm{~h}(14.2 \%)$; lane 8: $12 \mathrm{~h} \mathrm{(24.2 \% );} \mathrm{lane} \mathrm{9:} 24 \mathrm{~h}$ (38.6\%). Condition: duplex 7 was irradiated by $350 \mathrm{~nm}$ light in the presence of $2 \mathrm{mM} 3 \mathbf{b}$.

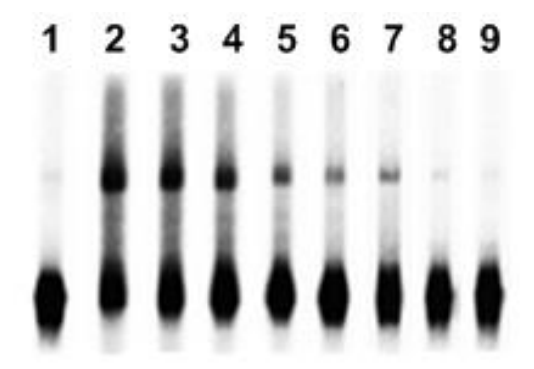

Figure S5. Representative gel of the effect of BME on DNA cross-link formation induced by 3a upon UV irradiation. Lane 1: with DNA only; lane 2: $2 \mathrm{mM}$ 3a (crosslinking yield 21.2\%); lane 3: $2 \mathrm{mM} \mathrm{3a}$ and $1 \mathrm{mM}$ BME (18.1\%); lane 4: $2 \mathrm{mM}$ 3a and 2 $\mathrm{mM}$ BME (13.5\%); lane 5: $2 \mathrm{mM} 3 \mathrm{a}$ and $5 \mathrm{mM}$ BME (7.1\%); lane 6: $2 \mathrm{mM}$ 3a and 10 $\mathrm{mM}$ BME (3.9\%); lane 7: $2 \mathrm{mM}$ 3a and $20 \mathrm{mM}$ BME (2.7\%); lane 8: $2 \mathrm{mM}$ 3a and 50 $\mathrm{mM}$ BME (1.9\%); lane 9: $2 \mathrm{mM} 3 \mathrm{a}$ and $100 \mathrm{mM}$ BME (0.9\%). Condition: duplex 7 was irradiated by $350 \mathrm{~nm}$ light for $24 \mathrm{~h}$. 


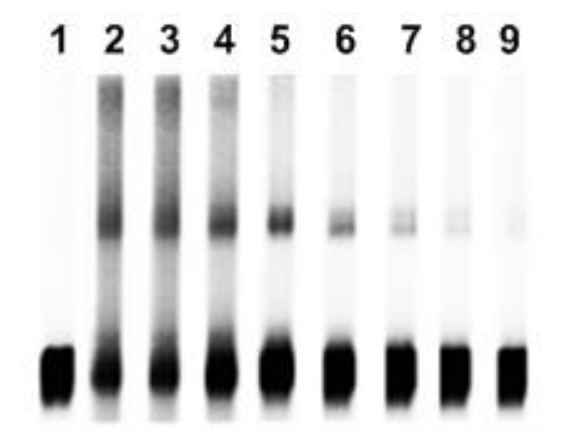

Figure S6. Representative gel of the effect of BME on DNA cross-link formation induced by $\mathbf{3 b}$ upon UV irradiation. Lane 1: with DNA only; lane 2: $2 \mathrm{mM}$ 3b (crosslinking yield 34.1\%); lane 3: $2 \mathrm{mM} \mathrm{3b}$ and $1 \mathrm{mM}$ BME (28.1\%); lane 4: $2 \mathrm{mM} \mathrm{3b}$ and 2 $\mathrm{mM}$ BME (18.3\%); lane 5: $2 \mathrm{mM} 3 \mathbf{b}$ and $5 \mathrm{mM}$ BME (14.7\%); lane 6: $2 \mathrm{mM} \mathbf{3 b}$ and 10 $\mathrm{mM}$ BME (7.9\%); lane 7: $2 \mathrm{mM} 3 \mathbf{b}$ and $20 \mathrm{mM}$ BME (4.3\%); lane 8: $2 \mathrm{mM} \mathbf{3 b}$ and 50 $\mathrm{mM}$ BME (2.2\%); lane 9: $2 \mathrm{mM}$ 3b and $100 \mathrm{mM} \mathrm{BME} \mathrm{(1.0 \% ).} \mathrm{Condition:} \mathrm{duplex} 7$ was irradiated by $350 \mathrm{~nm}$ light for $24 \mathrm{~h}$.

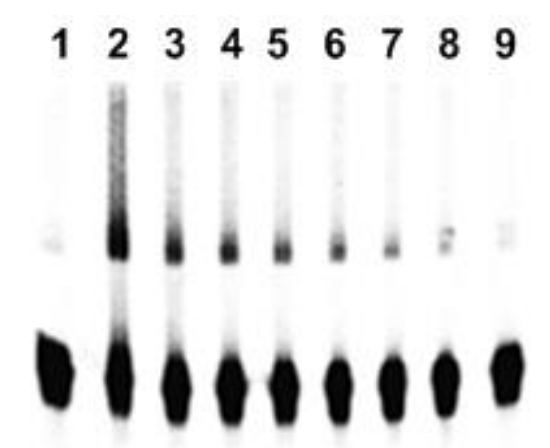

Figure S7. Representative gel of the effect of methoxyamine on DNA cross-link formation induced by 3a upon UV irradiation. Lane 1: with DNA only; lane 2: $2 \mathrm{mM}$ 3a (cross-linking yield 20.8\%); lane 3: $2 \mathrm{mM}$ 3a and $1 \mathrm{mM}$ methoxyamine (10.1\%); lane 4: $2 \mathrm{mM} 3 \mathrm{a}$ and $2 \mathrm{mM}$ methoxyamine (7.7\%); lane 5: $2 \mathrm{mM}$ 3a and $5 \mathrm{mM}$ methoxyamine (6.4\%); lane 6: $2 \mathrm{mM} 3 \mathrm{a}$ and $10 \mathrm{mM}$ methoxyamine (4.3\%); lane 7: $2 \mathrm{mM}$ 3a and $20 \mathrm{mM}$ methoxyamine (3.0\%); lane 8: $2 \mathrm{mM} \mathrm{3a}$ and $50 \mathrm{mM}$ methoxyamine (1.2\%); lane 9: 2 $\mathrm{mM} 3 \mathrm{a}$ and $100 \mathrm{mM}$ methoxyamine $(0.5 \%)$. Condition: duplex 7 was irradiated by 350 nm light for $24 \mathrm{~h}$.

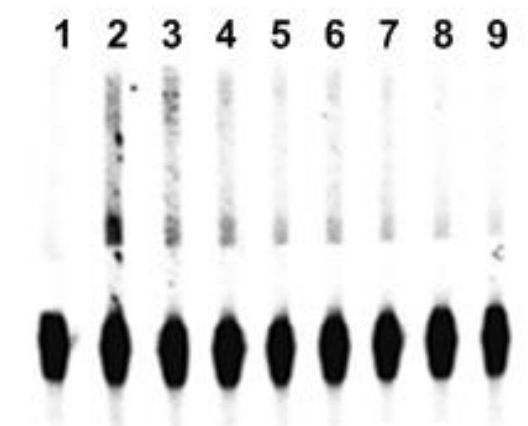

Figure S8. Representative gel of the effect of methoxyamine on DNA cross-link formation induced by $\mathbf{3 b}$ upon UV irradiation. Lane 1: with DNA only; lane 2: $2 \mathrm{mM} \mathbf{3 b}$ 
(cross-linking yield 32.3\%); lane 3: $2 \mathrm{mM} \mathrm{3b}$ and $1 \mathrm{mM}$ methoxyamine (20.1\%); lane 4: $2 \mathrm{mM} \mathrm{3b}$ and $2 \mathrm{mM}$ methoxyamine (14.7\%); lane 5: $2 \mathrm{mM} \mathrm{3b}$ and $5 \mathrm{mM}$ methoxyamine (11.6\%); lane 6: $2 \mathrm{mM} \mathrm{3b}$ and $10 \mathrm{mM}$ methoxyamine (7.8\%); lane 7: $2 \mathrm{mM} \mathrm{3b}$ and 20 $\mathrm{mM}$ methoxyamine (5.1\%); lane 8: $2 \mathrm{mM} \mathrm{3b}$ and $50 \mathrm{mM}$ methoxyamine (2.5\%); lane 9: $2 \mathrm{mM} \mathrm{3b}$ and $100 \mathrm{mM}$ methoxyamine (1.1\%). Condition: duplex 7 was irradiated by 350 $\mathrm{nm}$ light for $24 \mathrm{~h}$.

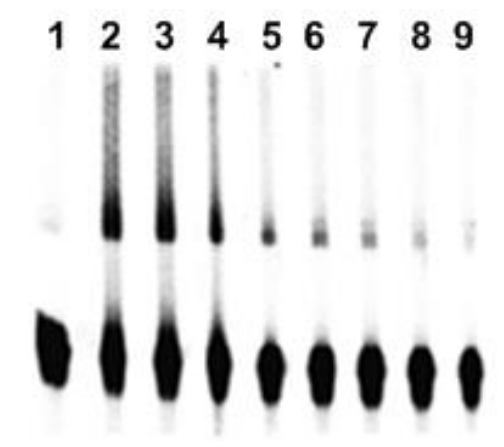

Figure S9. Representative gel of the effect of TEMPO on DNA cross-link formation induced by 3a upon UV irradiation. Lane 1: with DNA only; lane 2: $2 \mathrm{mM}$ 3a (crosslinking yield 20.8\%); lane 3: $2 \mathrm{mM} \mathrm{3a}$ and $1 \mathrm{mM}$ TEMPO (18.5\%); lane 4: $2 \mathrm{mM} \mathrm{3a}$ and $2 \mathrm{mM}$ TEMPO (11.0\%); lane 5: $2 \mathrm{mM}$ 3a and $5 \mathrm{mM}$ TEMPO (5.9\%); lane 6: $2 \mathrm{mM}$ 3a and $10 \mathrm{mM}$ TEMPO (4.1\%); lane 7: $2 \mathrm{mM}$ 3a and $20 \mathrm{mM}$ TEMPO (3.1\%); lane 8: $2 \mathrm{mM}$ 3a and $50 \mathrm{mM}$ TEMPO (2.2\%); lane 9: $2 \mathrm{mM} \mathrm{3a}$ and $100 \mathrm{mM}$ TEMPO (1.1\%). Condition: duplex 7 was irradiated by $350 \mathrm{~nm}$ light for $24 \mathrm{~h}$.

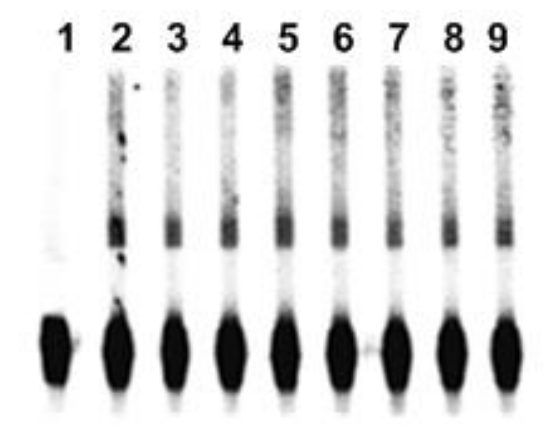

Figure S10. Representative gel of the effect of TEMPO on DNA cross-link formation induced by $\mathbf{3 b}$ upon UV irradiation. Lane 1: with DNA only; lane 2: $2 \mathrm{mM} \mathbf{3 b}$ (crosslinking yield 32.3\%); lane 3: $2 \mathrm{mM} \mathrm{3b}$ and $1 \mathrm{mM}$ TEMPO (30.8\%); lane 4: $2 \mathrm{mM} \mathbf{3 b}$ and $2 \mathrm{mM}$ TEMPO (31.4\%); lane 5: $2 \mathrm{mM} 3 \mathbf{b}$ and $5 \mathrm{mM}$ TEMPO (30.6\%); lane 6: $2 \mathrm{mM} \mathbf{3 b}$ and $10 \mathrm{mM}$ TEMPO (29.5\%); lane 7: $2 \mathrm{mM} \mathrm{3b}$ and $20 \mathrm{mM}$ TEMPO (27.1\%); lane 8: 2 $\mathrm{mM} \mathbf{3 b}$ and $50 \mathrm{mM}$ TEMPO (26.2\%); lane 9: $2 \mathrm{mM} \mathrm{3b}$ and $100 \mathrm{mM}$ TEMPO (22.1\%). Condition: duplex 7 was irradiated by $350 \mathrm{~nm}$ light for $24 \mathrm{~h}$. 

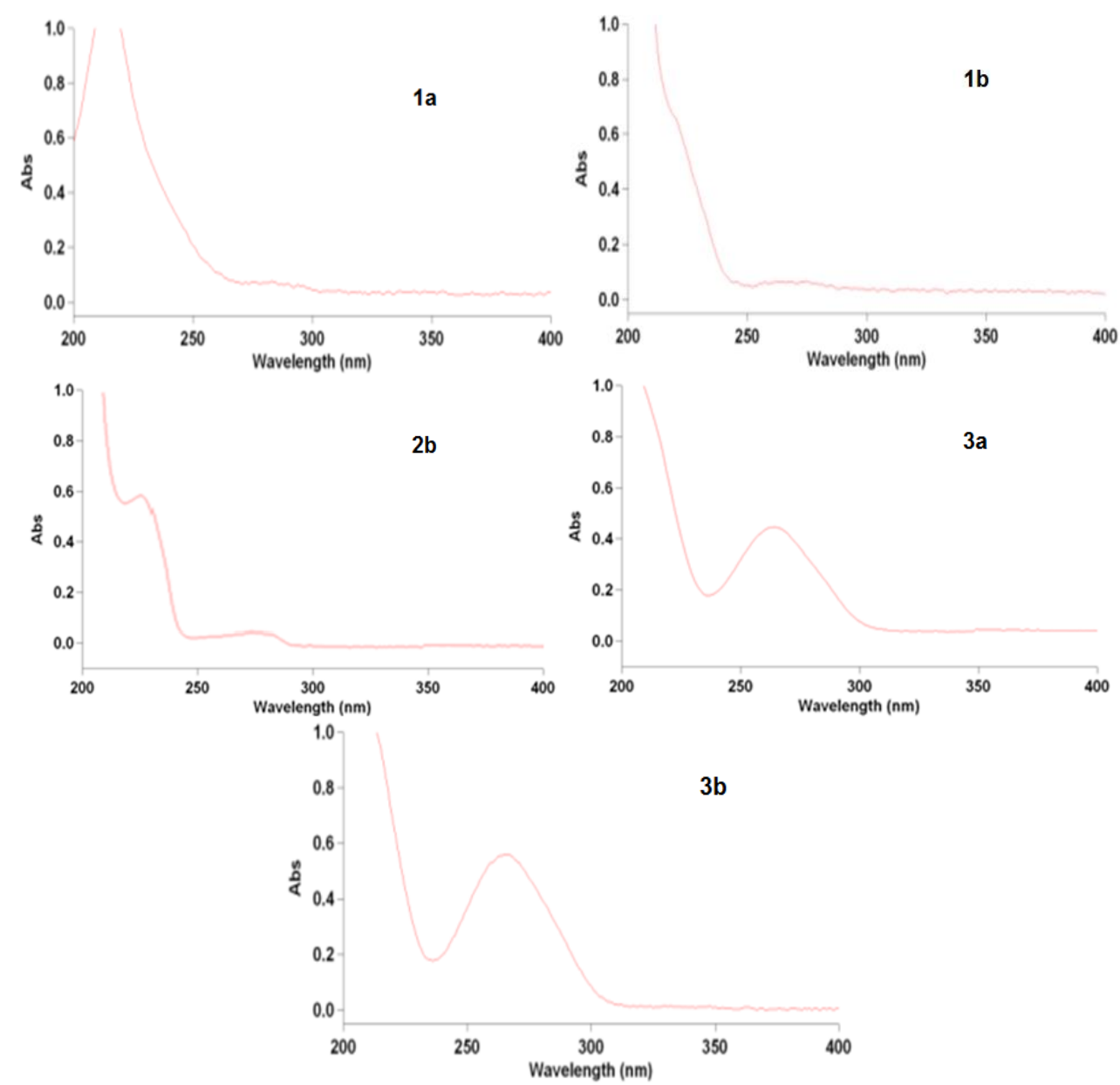

Figure S11. The UV absorbance of 1a $(400 \mu \mathrm{M})$, 1b $(400 \mu \mathrm{M}), \mathbf{2 b}(400 \mu \mathrm{M}), \mathbf{3 a}(400$ $\mu \mathrm{M})$, and $\mathbf{3 b}(400 \mu \mathrm{M})$.
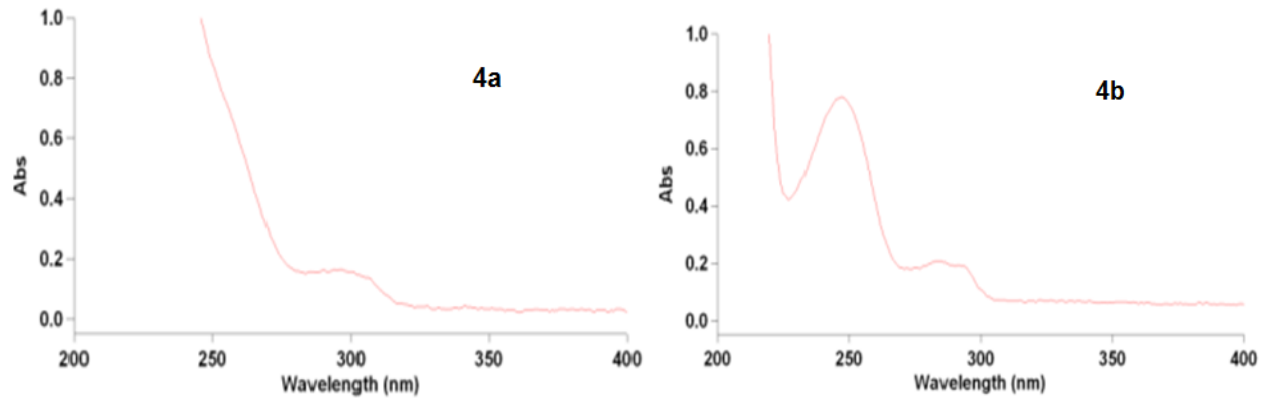

Figure S12. The UV absorbance of $\mathbf{4 a}(400 \mu \mathrm{M})$ and $\mathbf{4 b}(400 \mu \mathrm{M})$. 


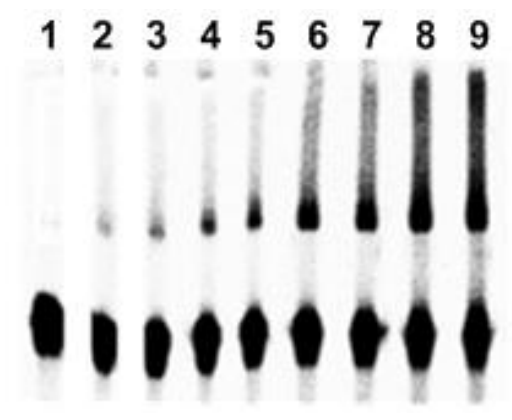

Figure S13. Representative gel of concentration dependence for DNA cross-link formation induced by 4a upon UV irradiation. Lane 1: with DNA only; lane 2: $20 \mu \mathrm{M} \mathrm{4a}$ (cross-linking yield 1.1\%); lane 3: $50 \mu \mathrm{M} \mathrm{4a} \mathrm{(1.9 \% );} \mathrm{lane} \mathrm{4:} 100 \mu \mathrm{M}$ 4a (3.1\%); lane 5: $200 \mu \mathrm{M}$ 4a (4.7\%); lane 6: $500 \mu \mathrm{M}$ 4a (11.3\%); lane 7: $1 \mathrm{mM}$ 4a (15.8\%); lane 8: $2 \mathrm{mM}$ 4a (23.1\%); lane 9: $5 \mathrm{mM} \mathrm{4a} \mathrm{(28.1 \% ).} \mathrm{Condition:} \mathrm{duplex} 7$ was irradiated by $350 \mathrm{~nm}$ light for $8 \mathrm{~h}$.

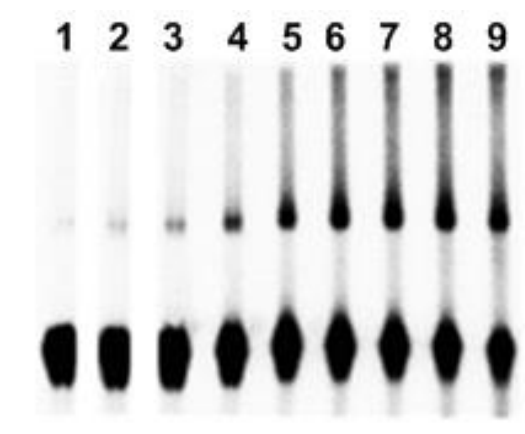

Figure S14. Representative gel of time dependence for DNA cross-link formation induced by 4a upon UV irradiation. Lane 1: no UV irradiation; lane 2: UV for $30 \mathrm{~min}$ (cross-linking yield 1.4\%); lane 3: $1 \mathrm{~h}(3.4 \%)$; lane 4: $2 \mathrm{~h} \mathrm{(6.3 \% );} \mathrm{lane} \mathrm{5:} 4 \mathrm{~h}(12.8 \%)$; lane 6: $6 \mathrm{~h} \mathrm{(19.7 \% );} \mathrm{lane} \mathrm{7:} 8 \mathrm{~h}(23.5 \%)$; lane 8: $12 \mathrm{~h}$ (27.3\%); lane 9: $24 \mathrm{~h} \mathrm{(31.8 \% ).}$ Condition: duplex 7 was irradiated by $350 \mathrm{~nm}$ light in the presence of $2 \mathrm{mM} \mathrm{4a}$.

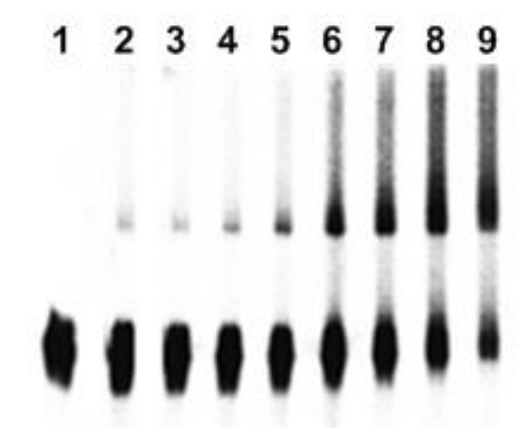

Figure S15. Representative gel of concentration dependence for DNA cross-link formation induced by $\mathbf{4}$ bupon UV irradiation. Lane 1: with DNA only; lane 2: $20 \mu \mathrm{M} \mathbf{4 b}$ (cross-linking yield 0.9\%); lane 3: $50 \mu \mathrm{M} \mathbf{4 b}(1.5 \%)$; lane 4: $100 \mu \mathrm{M}$ 4b (5.0\%); lane 5: $200 \mu \mathrm{M} 4 \mathbf{b}$ (9.3\%); lane 6: $500 \mu \mathrm{M}$ 4b (22.3\%); lane 7: $1 \mathrm{mM}$ 4b (33.4\%); lane 8: $2 \mathrm{mM}$ 4b (51.1\%); lane 9: $5 \mathrm{mM} \mathrm{4b}$ (65.5\%). Condition: duplex 7 was irradiated by $350 \mathrm{~nm}$ light for $8 \mathrm{~h}$. 


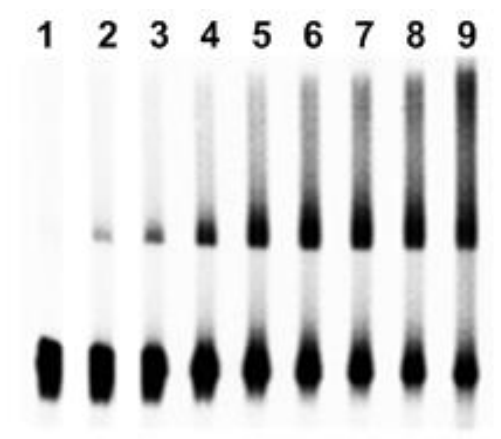

Figure S16. Representative gel of time dependence for DNA cross-link formation induced by $\mathbf{4 b}$ upon UV irradiation. Lane 1: no UV irradiation; lane 2: UV for $30 \mathrm{~min}$ (cross-linking yield 4.3\%); lane 3: $1 \mathrm{~h}(9.9 \%)$; lane 4: $2 \mathrm{~h}(20.1 \%)$; lane 5: $4 \mathrm{~h}(35.6 \%)$; lane 6: 6 h (45.0\%); lane 7: 8 h (49.0\%); lane 8: 12 h (54.4\%); lane 9: 24 h (60.6\%). Condition: duplex 7 was irradiated by $350 \mathrm{~nm}$ light in the presence of $2 \mathrm{mM} \mathbf{4 b}$.

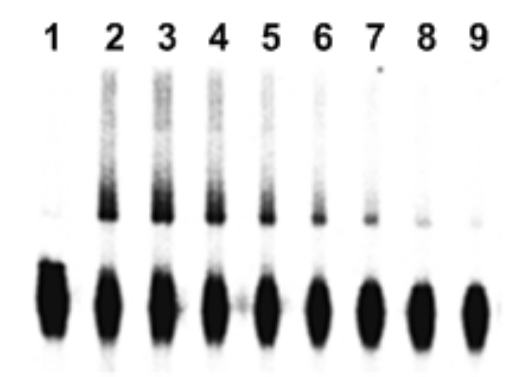

Figure S17. Representative gel of the effect of TEMPO on DNA cross-link formation induced by 4a upon UV irradiation. Lane 1: with DNA only; lane 2: $2 \mathrm{mM}$ 4a (crosslinking yield 22.9\%); lane 3: $2 \mathrm{mM}$ 4a and 1mM TEMPO (18.8\%); lane 4: $2 \mathrm{mM}$ 4a and $2 \mathrm{mM}$ TEMPO (15.3\%); lane 5: $2 \mathrm{mM} \mathrm{4a}$ and $5 \mathrm{mM}$ TEMPO (10.1\%); lane 6: $2 \mathrm{mM}$ 4a and $10 \mathrm{mM}$ TEMPO (7.4\%); lane 7: $2 \mathrm{mM}$ 4a and $20 \mathrm{mM}$ TEMPO (4.8\%); lane 8: $2 \mathrm{mM}$ 4a and $50 \mathrm{mM}$ TEMPO (2.9\%); lane 9: $2 \mathrm{mM} \mathrm{4a}$ and $100 \mathrm{mM}$ TEMPO (1.7\%). Condition: duplex 7 was irradiated by $350 \mathrm{~nm}$ light for $8 \mathrm{~h}$.

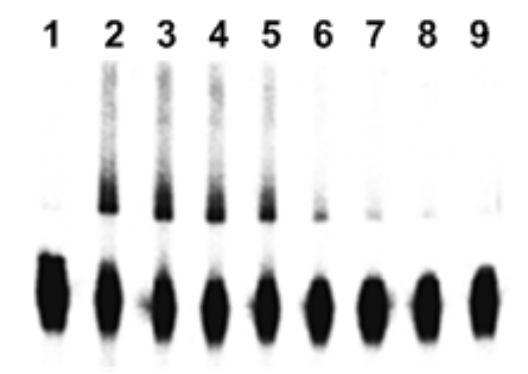

Figure S18. Representative gel of the effect of methoxyamine on DNA cross-link formation induced by 4a upon UV irradiation. Lane 1: with DNA only; lane 2: $2 \mathrm{mM}$ 4a (cross-linking yield 23.9\%); lane 3: $2 \mathrm{mM}$ 4a and $1 \mathrm{mM}$ methoxyamine (19.0\%); lane 4: $2 \mathrm{mM} 4 \mathrm{a}$ and $2 \mathrm{mM}$ methoxyamine (14.5\%); lane 5: $2 \mathrm{mM} \mathrm{4a}$ and $5 \mathrm{mM}$ methoxyamine (11.1\%); lane 6: $2 \mathrm{mM} \mathrm{4a}$ and $10 \mathrm{mM}$ methoxyamine (4.8\%); lane 7: $2 \mathrm{mM} \mathrm{4a}$ and 20 $\mathrm{mM}$ methoxyamine (3.1\%); lane $8: 2 \mathrm{mM}$ 4a and $50 \mathrm{mM}$ methoxyamine (1.8\%); lane 9: $2 \mathrm{mM} 4 \mathrm{a}$ and $100 \mathrm{mM}$ methoxyamine (0.9\%). Condition: duplex 7 was irradiated by 350 $\mathrm{nm}$ light for $8 \mathrm{~h}$. 


\section{$\begin{array}{lllllllll}1 & 2 & 3 & 4 & 5 & 6 & 7 & 8 & 9\end{array}$}

Figure S19. Representative gel of the effect of TEMPO on DNA cross-link formation induced by $\mathbf{4 b}$ upon UV irradiation. Lane 1: with DNA only; lane 2: $2 \mathrm{mM} \mathbf{4 b}$ (crosslinking yield 54.4\%); lane 3: $2 \mathrm{mM} \mathbf{4 b}$ and $1 \mathrm{mM}$ TEMPO (49.1\%); lane 4: $2 \mathrm{mM} 4 \mathbf{b}$ and $2 \mathrm{mM}$ TEMPO (44.6\%); lane 5: $2 \mathrm{mM} 4 \mathbf{b}$ and $5 \mathrm{mM}$ TEMPO (38.1\%); lane 6: $2 \mathrm{mM} \mathrm{4b}$ and $10 \mathrm{mM}$ TEMPO (36.1\%); lane 7: $2 \mathrm{mM} \mathbf{4 b}$ and $20 \mathrm{mM}$ TEMPO (35.8\%); lane 8: 2 $\mathrm{mM} \mathbf{4 b}$ and $50 \mathrm{mM}$ TEMPO (36.2\%); lane 9: $2 \mathrm{mM} 4 \mathbf{b}$ and $100 \mathrm{mM}$ TEMPO (35.8\%). Condition: duplex 7 was irradiated by $350 \mathrm{~nm}$ light for $8 \mathrm{~h}$.

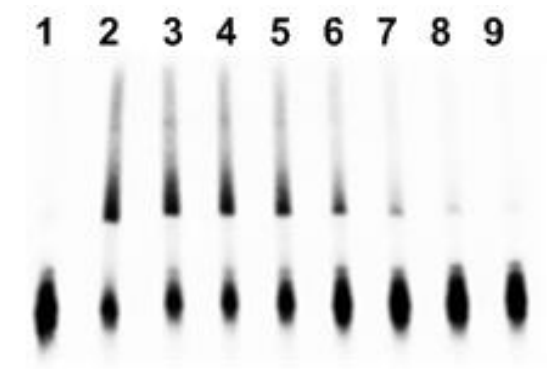

Figure S20. Representative gel of the effect of methoxyamine on DNA cross-link formation induced by $\mathbf{4 b}$ upon UV irradiation. Lane 1: with DNA only; lane 2: $2 \mathrm{mM} \mathbf{4 b}$ (cross-linking yield 58.4\%); lane 3: $2 \mathrm{mM} \mathbf{4 b}$ and $1 \mathrm{mM}$ methoxyamine (52.0\%); lane 4: $2 \mathrm{mM} 4 \mathbf{b}$ and $2 \mathrm{mM}$ methoxyamine (45.0\%); lane 5: $2 \mathrm{mM} \mathbf{4 b}$ and $5 \mathrm{mM}$ methoxyamine (39.7\%); lane 6: $2 \mathrm{mM} \mathrm{4b}$ and $10 \mathrm{mM}$ methoxyamine (22.4\%); lane 7: $2 \mathrm{mM} \mathrm{4b}$ and 20 $\mathrm{mM}$ methoxyamine (5.6\%); lane 8: $2 \mathrm{mM} \mathbf{4 b}$ and $50 \mathrm{mM}$ methoxyamine (2.5\%); lane 9: $2 \mathrm{mM} \mathbf{4 b}$ and $100 \mathrm{mM}$ methoxyamine (1.1\%). Condition: duplex 7 was irradiated by 350 $\mathrm{nm}$ light for $8 \mathrm{~h}$.
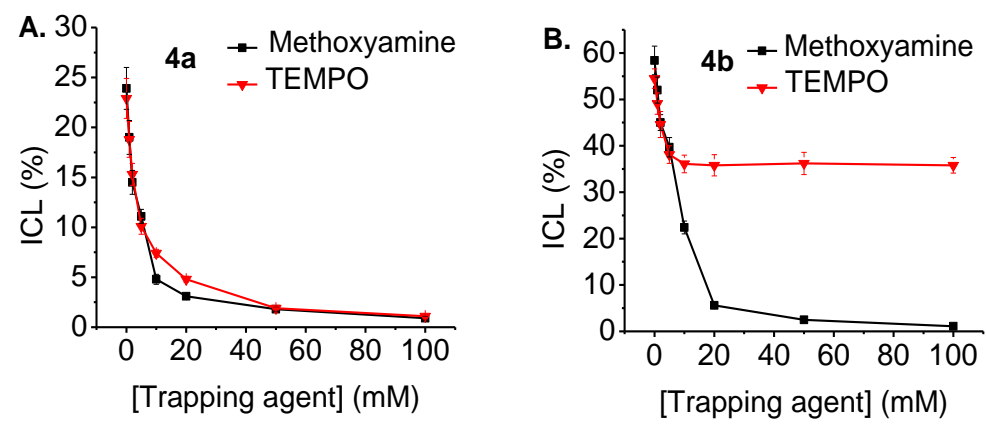

Figure S21. Effect of TEMPO and methoxyamine on DNA ICL formation of duplex 7 induced by $4 \mathbf{a}(\mathbf{A})$, and $\mathbf{4 b}(\mathbf{B})$. 


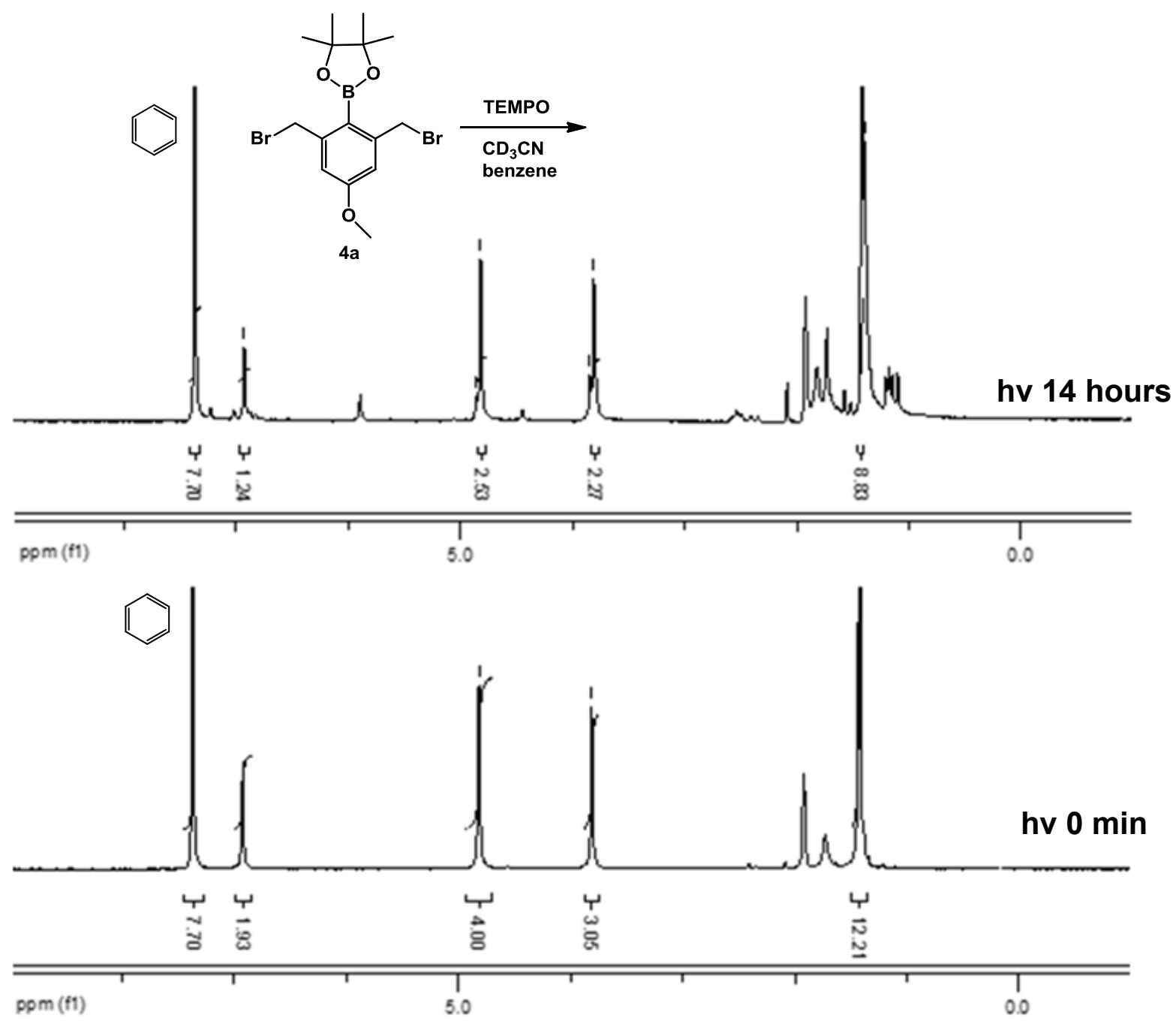

Figure S22. ${ }^{1} \mathrm{H}$ NMR analysis of $\mathbf{4 a}(0.002 \mathrm{mmol})$ in deuterated acetonitrile- $\mathrm{d}_{3}$, TEMPO ( $0.08 \mathrm{mmol}, 4.0$ equiv.), and benzene as an internal standard. 


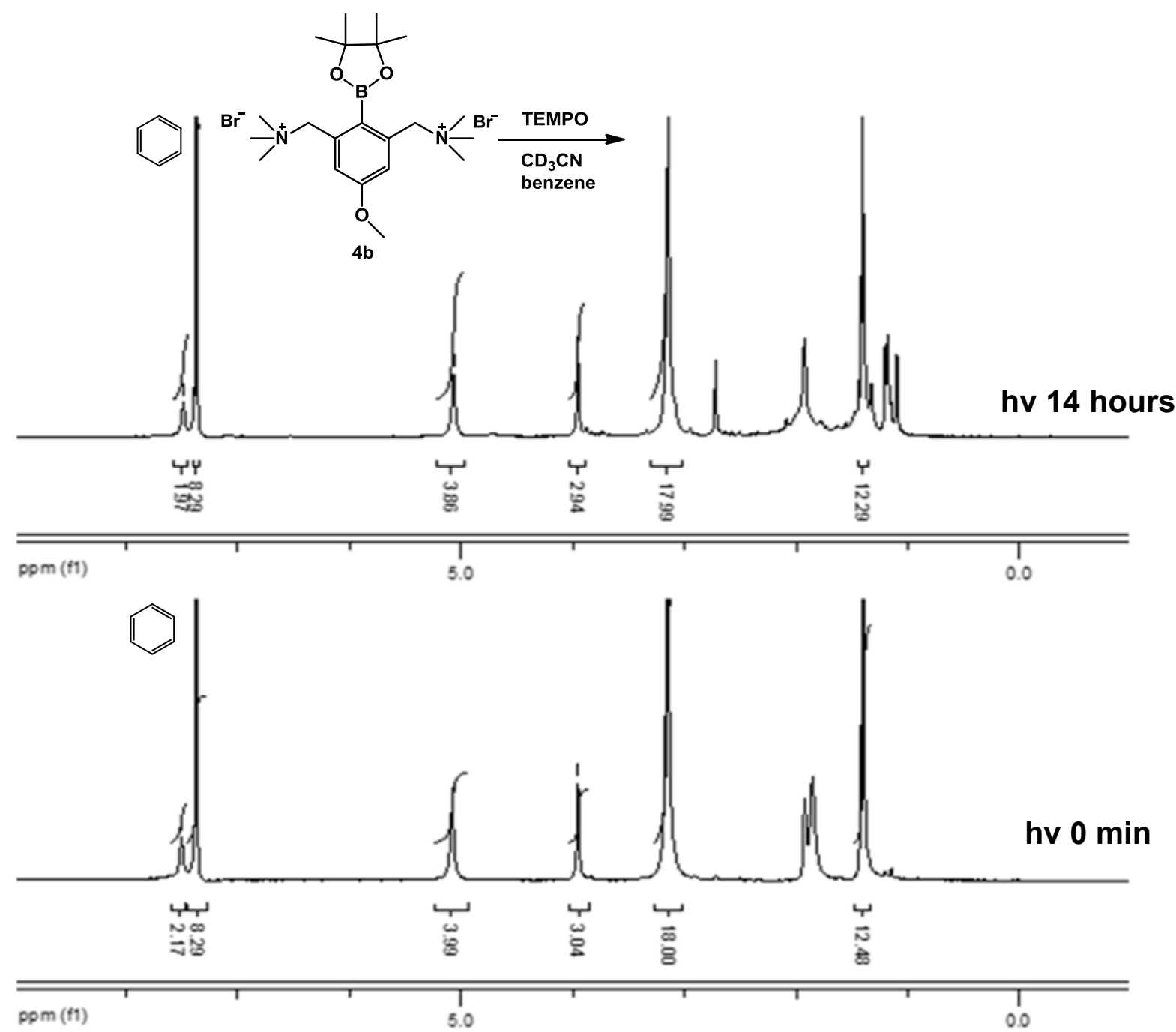

Figure S23. ${ }^{1} \mathrm{H}$ NMR analysis of $\mathbf{4 b}(0.002 \mathrm{mmol})$ in deuterated acetonitrile- $\mathrm{d}_{3}$, TEMPO ( $0.08 \mathrm{mmol}, 4.0$ equiv.), and benzene as an internal standard. 


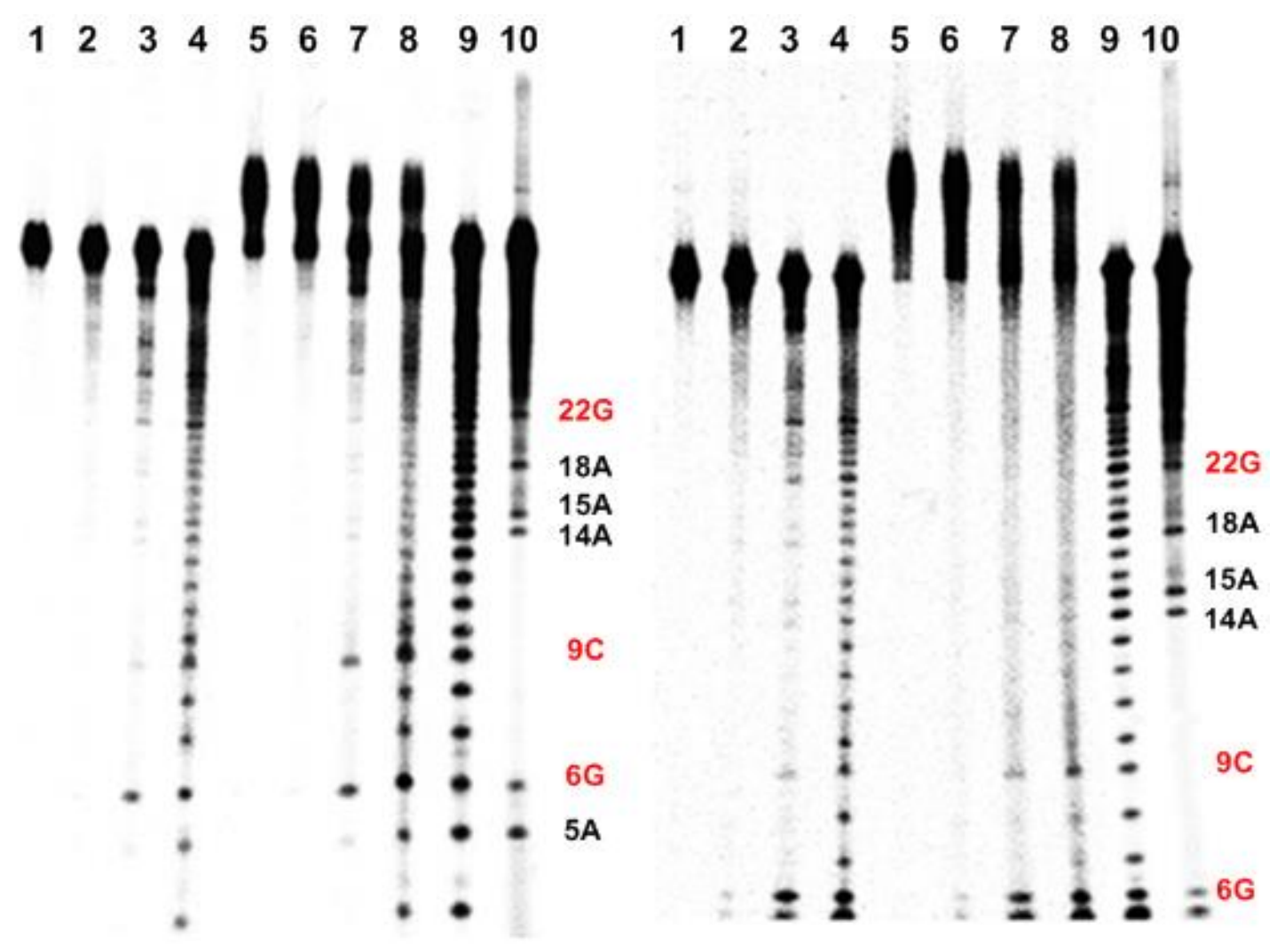

Figure S24. Determination of cross-linking site of $\mathbf{4 a}$ and $\mathbf{4 b}$. Phosphorimage autoradiogram of $20 \%$ denaturing PAGE analysis of the isolated ICL products and

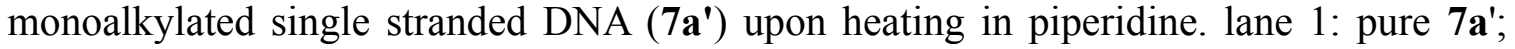
lane 2: heating of $7 \mathbf{a}^{\prime}$ in phosphate buffer at $90{ }^{\circ} \mathrm{C}$ for $30 \mathrm{~min}$; lane 3 : heating of $7 \mathbf{a}^{\prime}$ in 1.0 $\mathrm{M}$ piperidine at $90{ }^{\circ} \mathrm{C}$ for $30 \mathrm{~min}$; lane 4: Fe.EDTA treatment of 7a'; lane 5: pure isolated ICL product; lane 6: heating of ICL in phosphate bufferat $90{ }^{\circ} \mathrm{C}$ for $30 \mathrm{~min}$; lane 7: heating of ICL in $1.0 \mathrm{M}$ piperidine at $90{ }^{\circ} \mathrm{C}$ for $30 \mathrm{~min}$; lane 8: Fe.EDTA treatment of ICL; lane 9: Fe·EDTA treatment of 7; lane 10: G+A sequencing. 


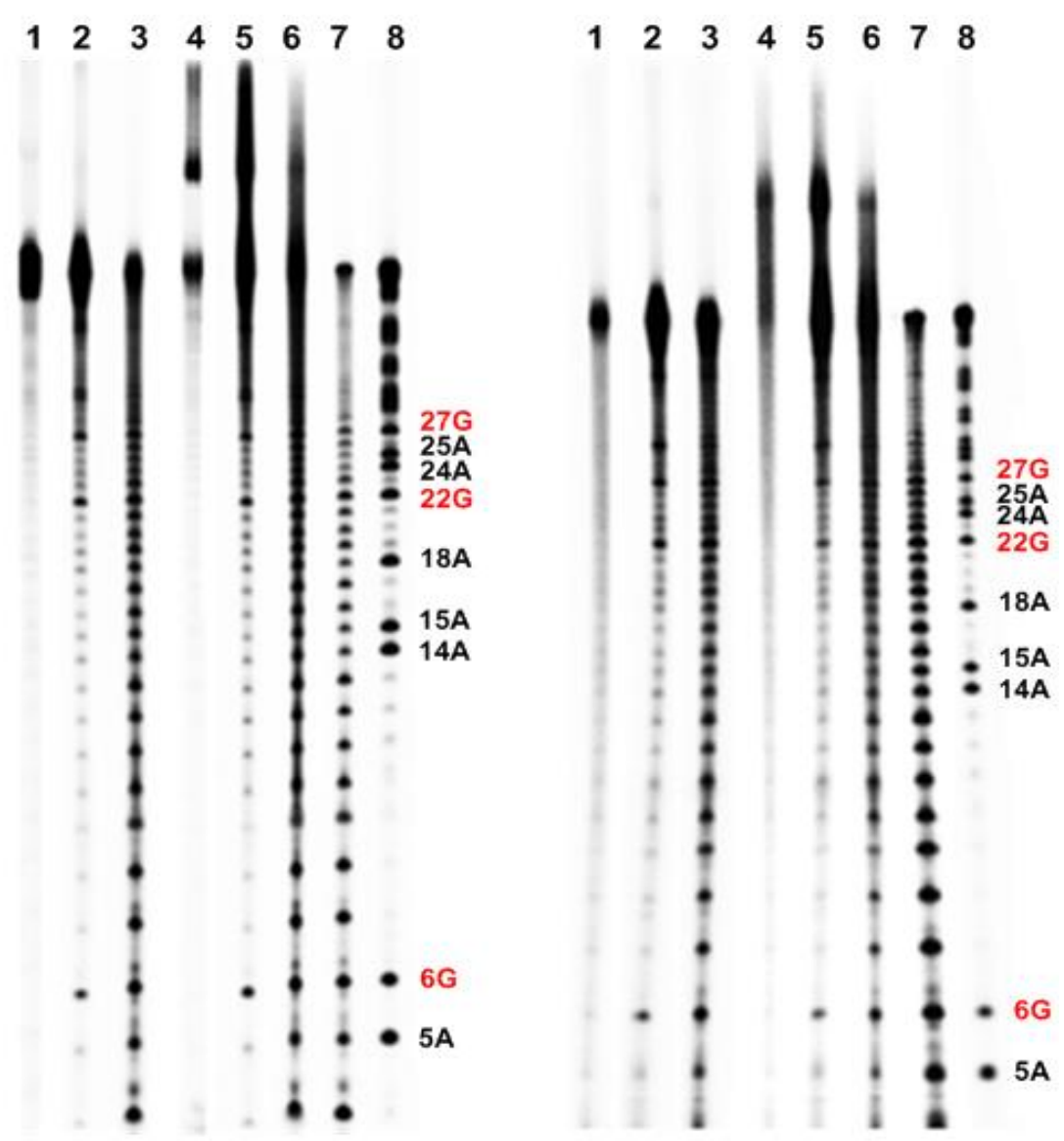

Figure S25. Determination of cross-linking site of $\mathbf{3 a}$ and $\mathbf{3 b}$. Phosphorimage autoradiogram of $20 \%$ denaturing PAGE analysis of the isolated ICL products and monoalkylated single stranded DNA (7a') upon heating in piperidine. lane 1: heating of $7 \mathbf{a}^{\prime}$ in phosphate buffer at $90{ }^{\circ} \mathrm{C}$ for $30 \mathrm{~min}$; lane 2: heating of $7 \mathbf{a}^{\prime}$ in $1.0 \mathrm{M}$ piperidine at $90{ }^{\circ} \mathrm{C}$ for $30 \mathrm{~min}$; lane 3: Fe·EDTA treatment of 7a'; lane 4: heating of ICL product in phosphate buffer at $90{ }^{\circ} \mathrm{C}$ for $30 \mathrm{~min}$; lane 5: heating of ICL product in $1.0 \mathrm{M}$ piperidine at $90{ }^{\circ} \mathrm{C}$ for $30 \mathrm{~min}$; lane 6: Fe-EDTA treatment of ICL; lane 7: Fe EDTA treatment of 7; lane 8: $\mathrm{G}+\mathrm{A}$ sequencing.

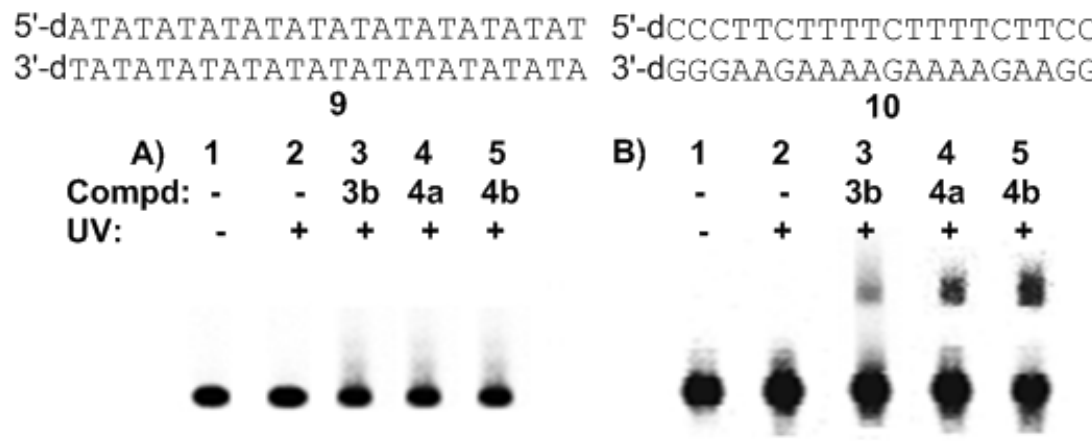

Figure S26. Phosphorimage autoradiogram of $20 \%$ denaturing PAGE analysis of crosslinking formation with DNA duplex 9 (A) and $\mathbf{1 0}$ (B) induced by $\mathbf{3 b}$ and $\mathbf{4 a}, \mathbf{b}$ upon UV irradiation for $8 \mathrm{~h}$. 

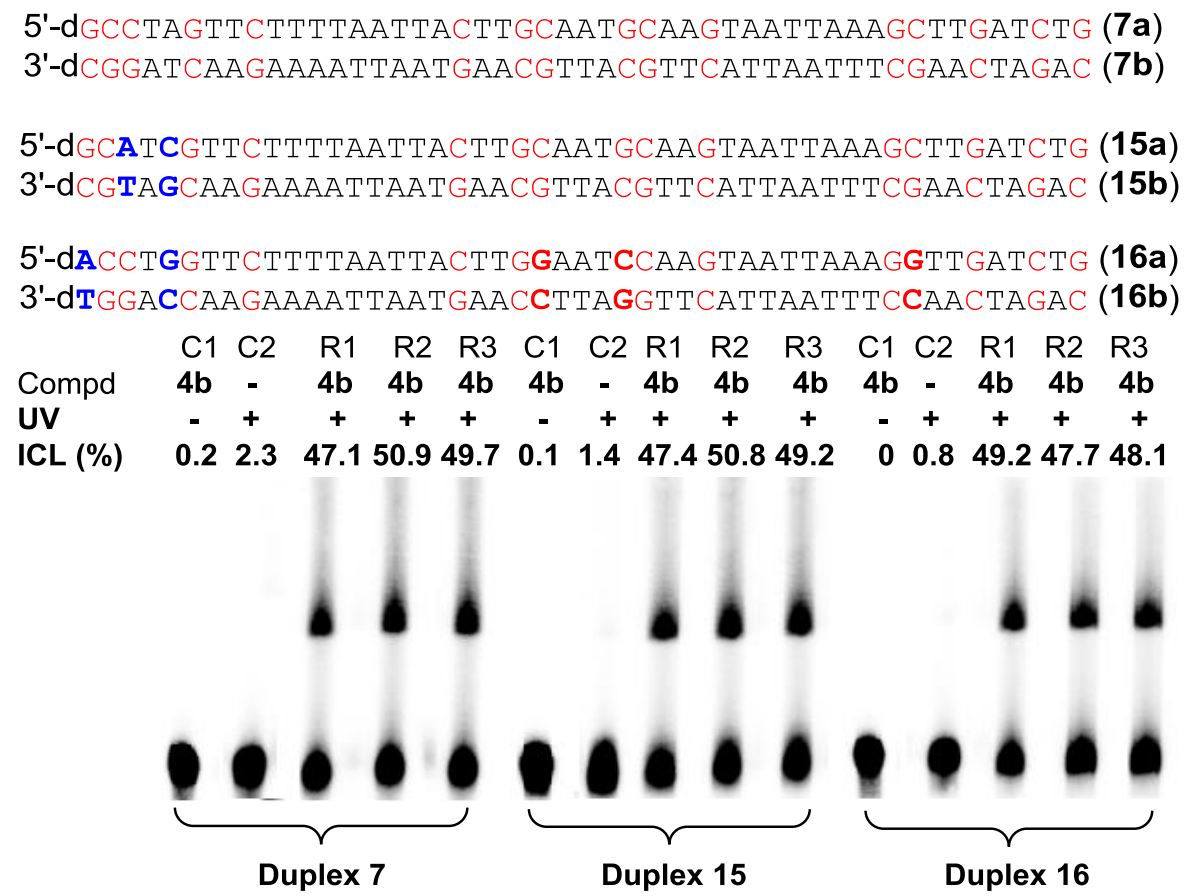

Figure S27. Phosphorimage autoradiogram of $20 \%$ denaturing PAGE analysis of crosslinking formation with DNA duplexes 7, 15, and 16 induced by $\mathbf{4 b}$ upon UV irradiation for $8 \mathrm{~h}$ [Note: Two control experiments were performed: $\mathrm{Cl}$ (ODN $+\mathbf{4 b}$ without $\mathrm{UV}$ irradiation) and C2 (ODN with UV irradiation in the absence of $\mathbf{4 b}$. The final ICL yields induced by $\mathbf{4 b}$ were obtained from three parallel experiments (R1, R2, and R3) where the background ICL yields $(\mathrm{C} 1+\mathrm{C} 2)$ were abstracted].

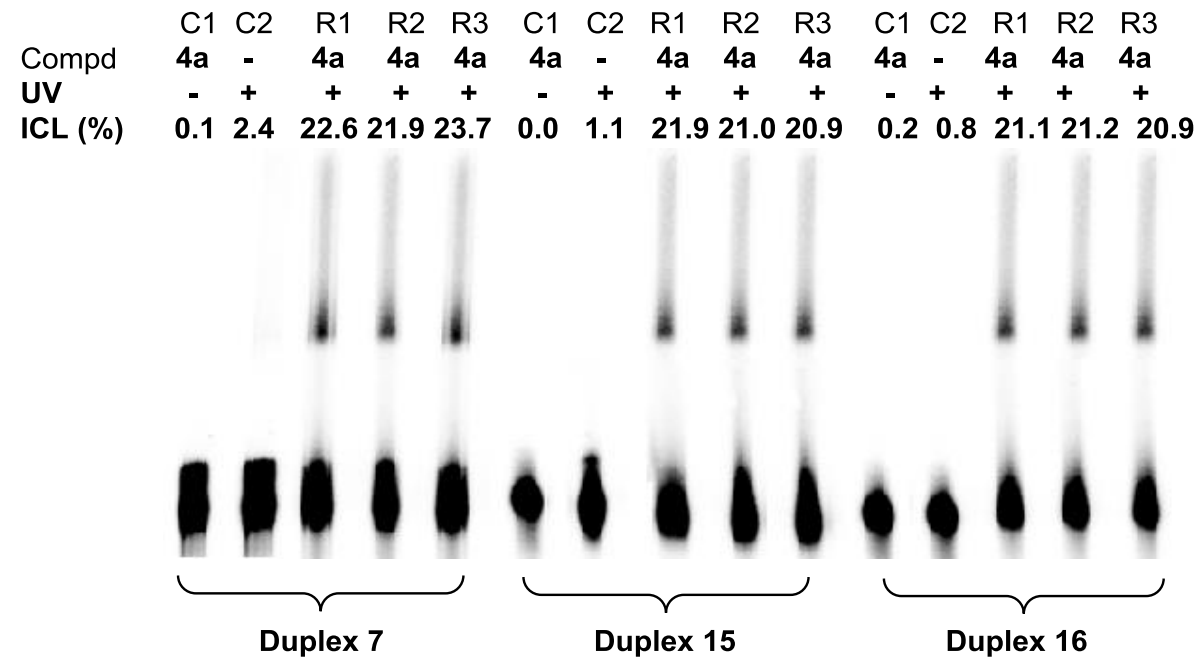

Figure S28. Phosphorimage autoradiogram of 20\% denaturing PAGE analysis of crosslinking formation with DNA duplex 7, 15, and 16 induced by 4a upon UV irradiation for $8 \mathrm{~h}$ (final ICL yields: $20.2 \pm 0.9 \%$ for duplex 7, $20.8 \pm 0.9 \%$ for duplex 15, and $19.7 \pm$ $0.6 \%$ for duplex 16) [Note: Two control experiments were performed: C1 (ODN + 4a without UV irradiation) and C2 (ODN with UV irradiation in the absence of 4a. The final ICL yields induced by $\mathbf{4 a}$ were obtained from three parallel experiments (R1, R2, and R3) where the background ICL yields $(\mathrm{C} 1+\mathrm{C} 2)$ were abstracted]. 
Scheme S2. Radical trapping reactions with TEMPO

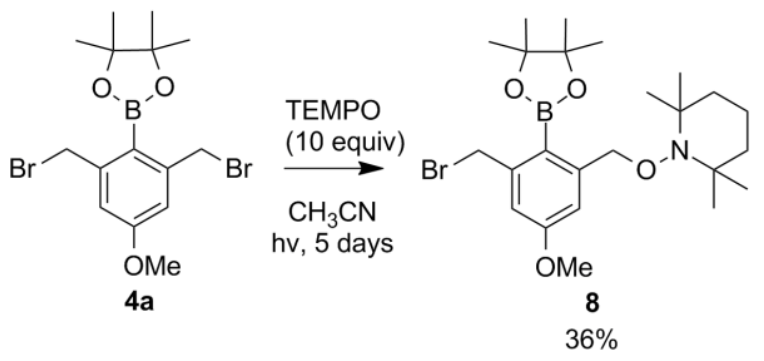

Scheme S3. Proposed mechanism for ICL formation induced by $\mathbf{3 a}$ and $\mathbf{3 b}$

A)
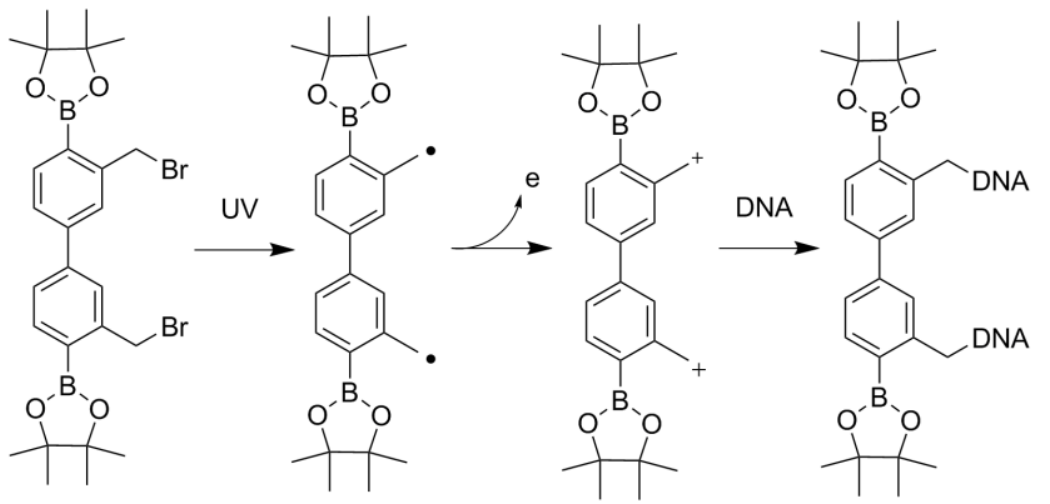

3a

B)
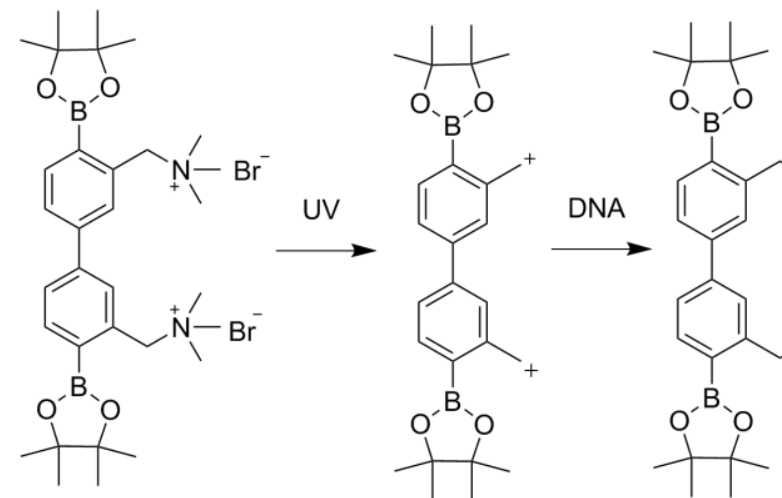

3b

Scheme S4. One-electron transfer occurred between the radical A and bromo radical which is indicated by formation of $\mathrm{AgBr}$ precipitates

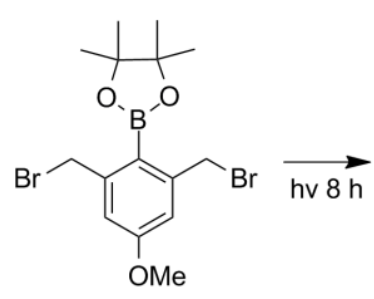

$4 a$

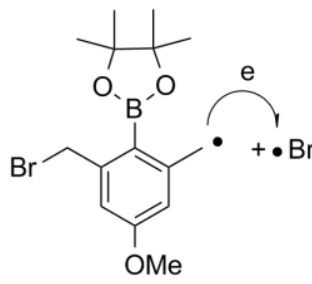

A

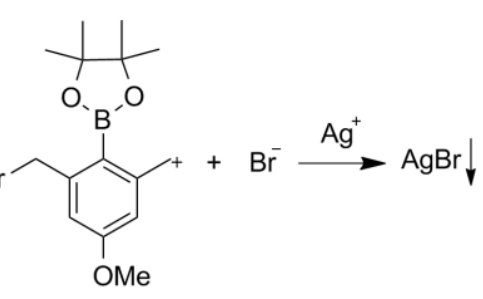

B 

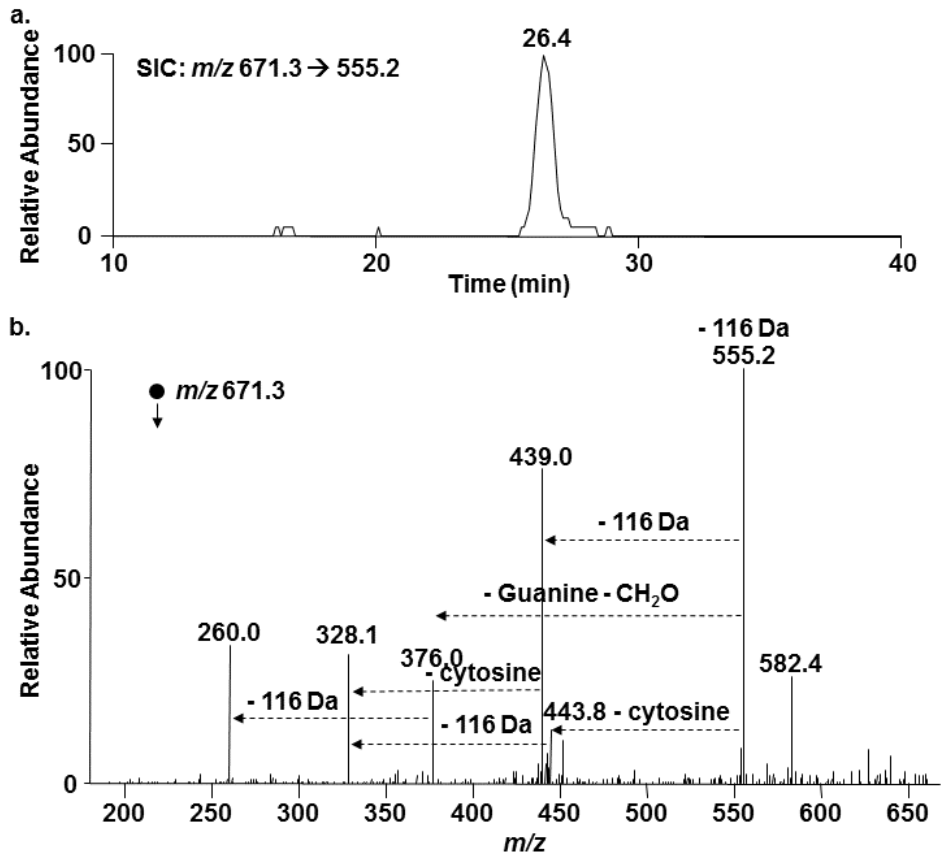

Figure S29. Identification of DNA cross-linking products formed with $\mathbf{4 b}$. (A) Selectedion chromatogram for monitoring the indicated transition for $\mathrm{dG}-\mathbf{4} \mathbf{b}^{*}$-dC cross-link in the digestion mixture. (B) Positive-ion ESI-MS/MS for $\mathrm{dG}-4 b^{*}-\mathrm{dC}$ eluting at $26.4 \mathrm{~min}$ in (a).

Scheme S5. The proposed structures for the ICL product and the proposed fragmentation pathway for the $[\mathrm{M}]^{+}$ion of $\mathrm{dG}-\mathbf{4} \mathbf{b}^{*}$-dC (11) cross-link observed in LC-MS/MS

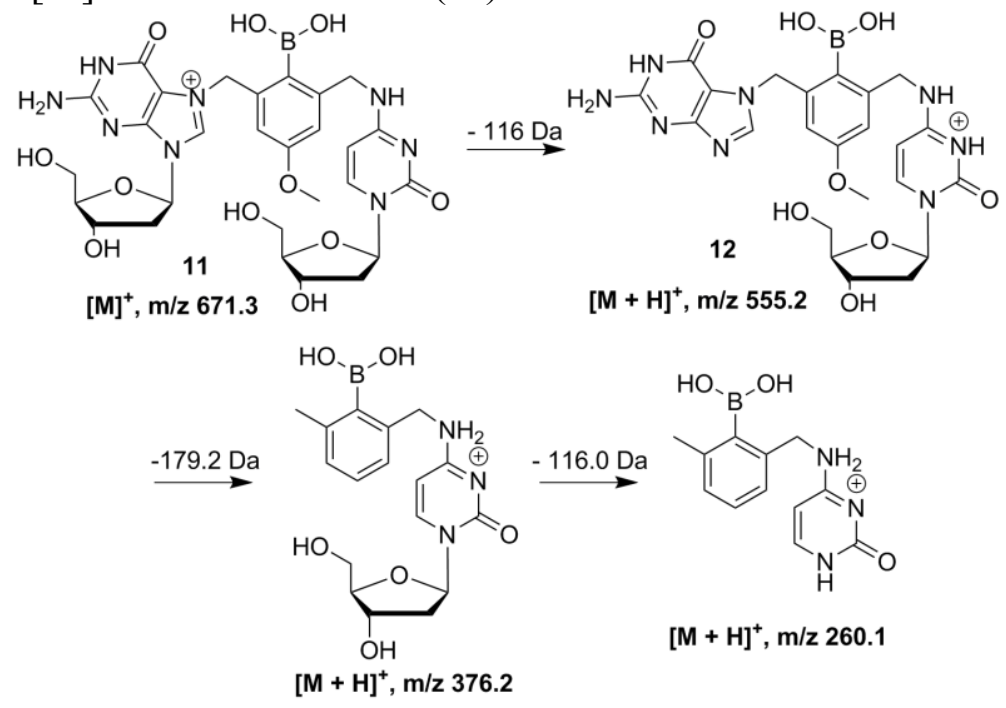



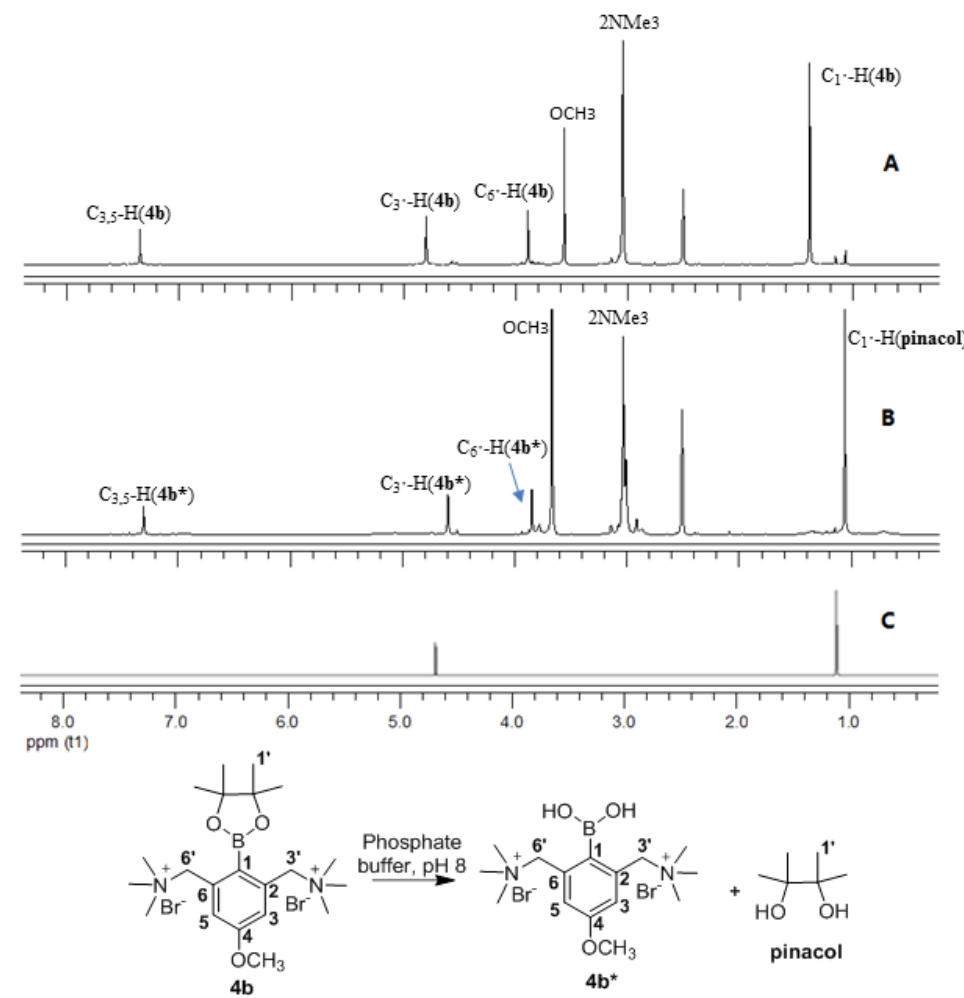

Figure S30. ${ }^{1} \mathrm{H}$ NMR analysis of hydrolysis of $\mathbf{4 b}(0.003 \mathrm{mmol})$ in deuterated DMSO and $\mathrm{D}_{2} \mathrm{O}$ : (A) ${ }^{1} \mathrm{H}$ NMR of $\mathbf{4 b}$ in DMSO $(300 \mu \mathrm{L})$ only; (B) 4 h incubation in a mixture of DMSO $(300 \mu \mathrm{L}), \mathrm{D}_{2} \mathrm{O}(20 \mu \mathrm{L})$, and $\mathrm{pH} 8$ deuterated phosphate buffer $(10 \mu \mathrm{L})$; $(\mathbf{C})$ pure pinacol in deuterated phosphate buffer. 


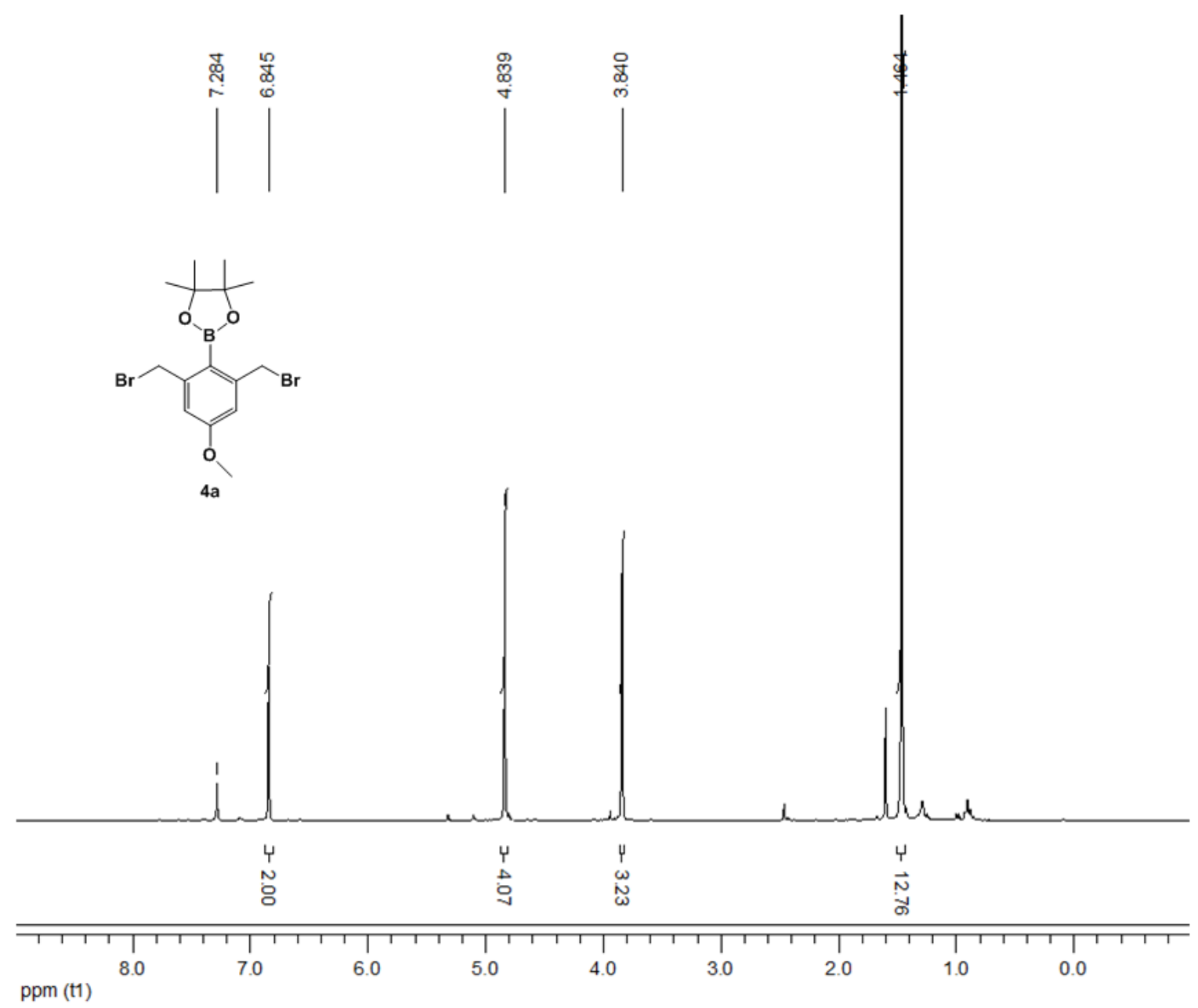

Figure S31. ${ }^{1} \mathrm{H}$ NMR spectra of $\mathbf{4 a}$. 


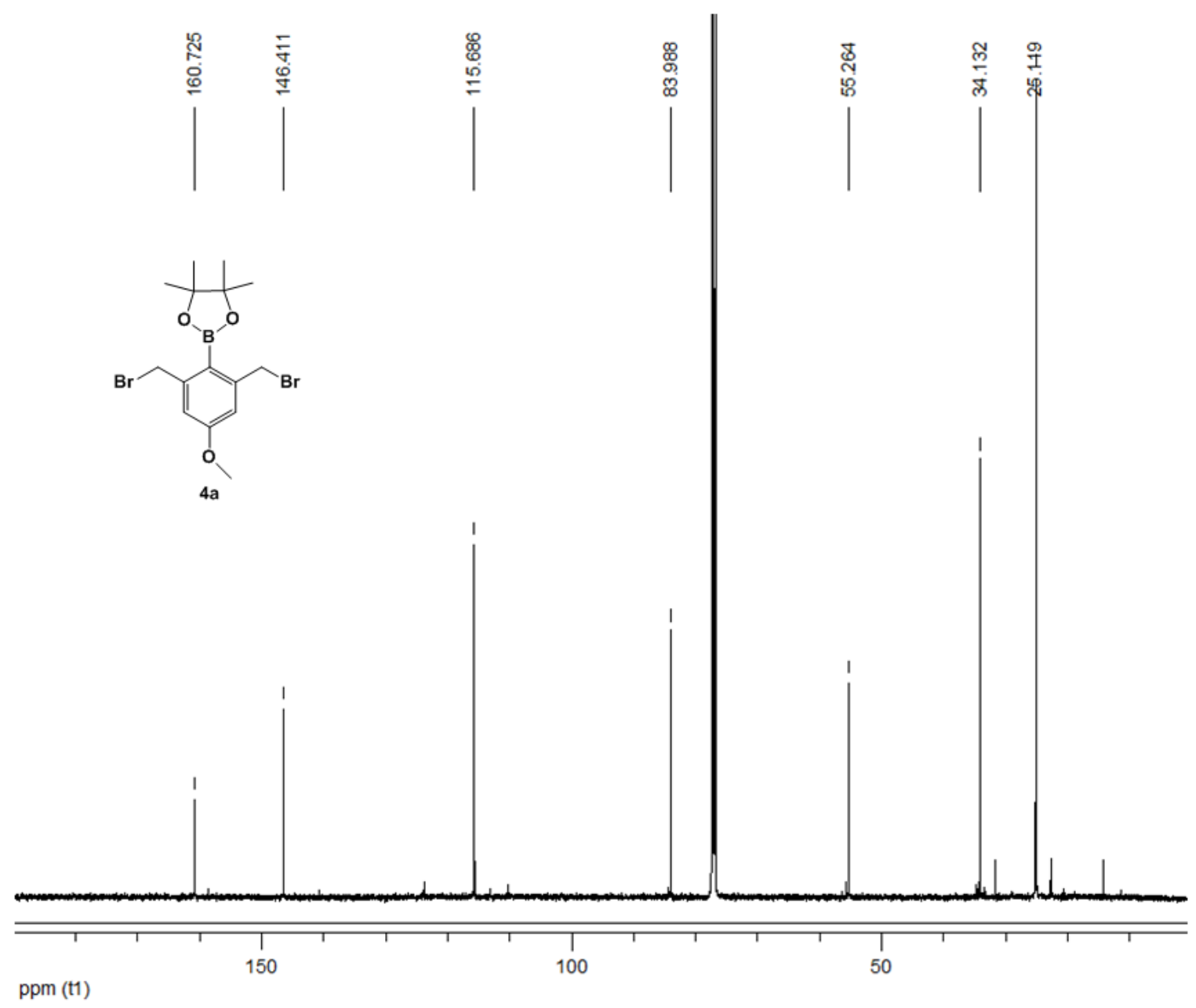

Figure S32. ${ }^{13} \mathrm{C}$ NMR spectra of $\mathbf{4 a}$. 


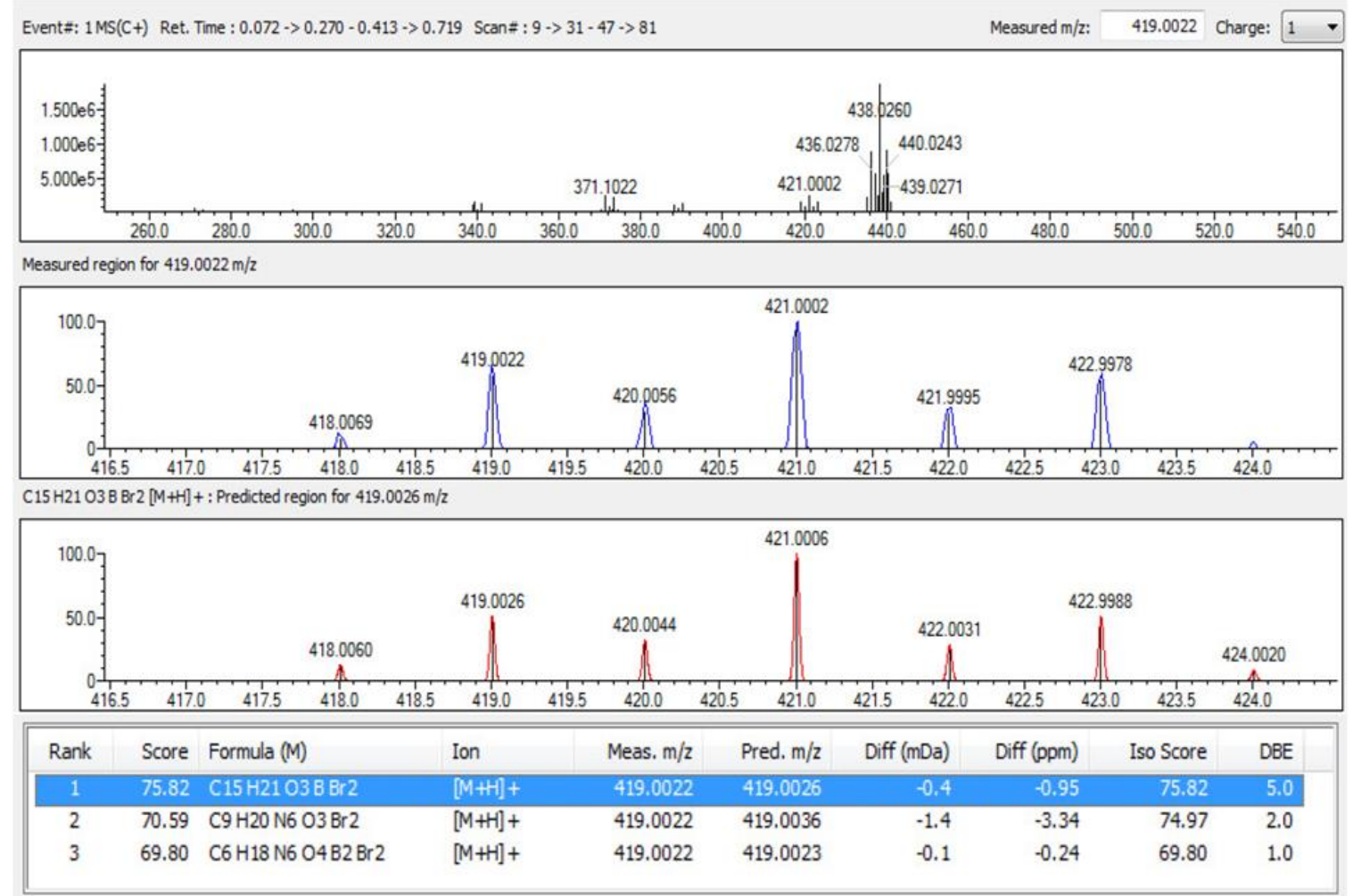

Figure S33. IT-TOF-MS (APCI) of 4a. 


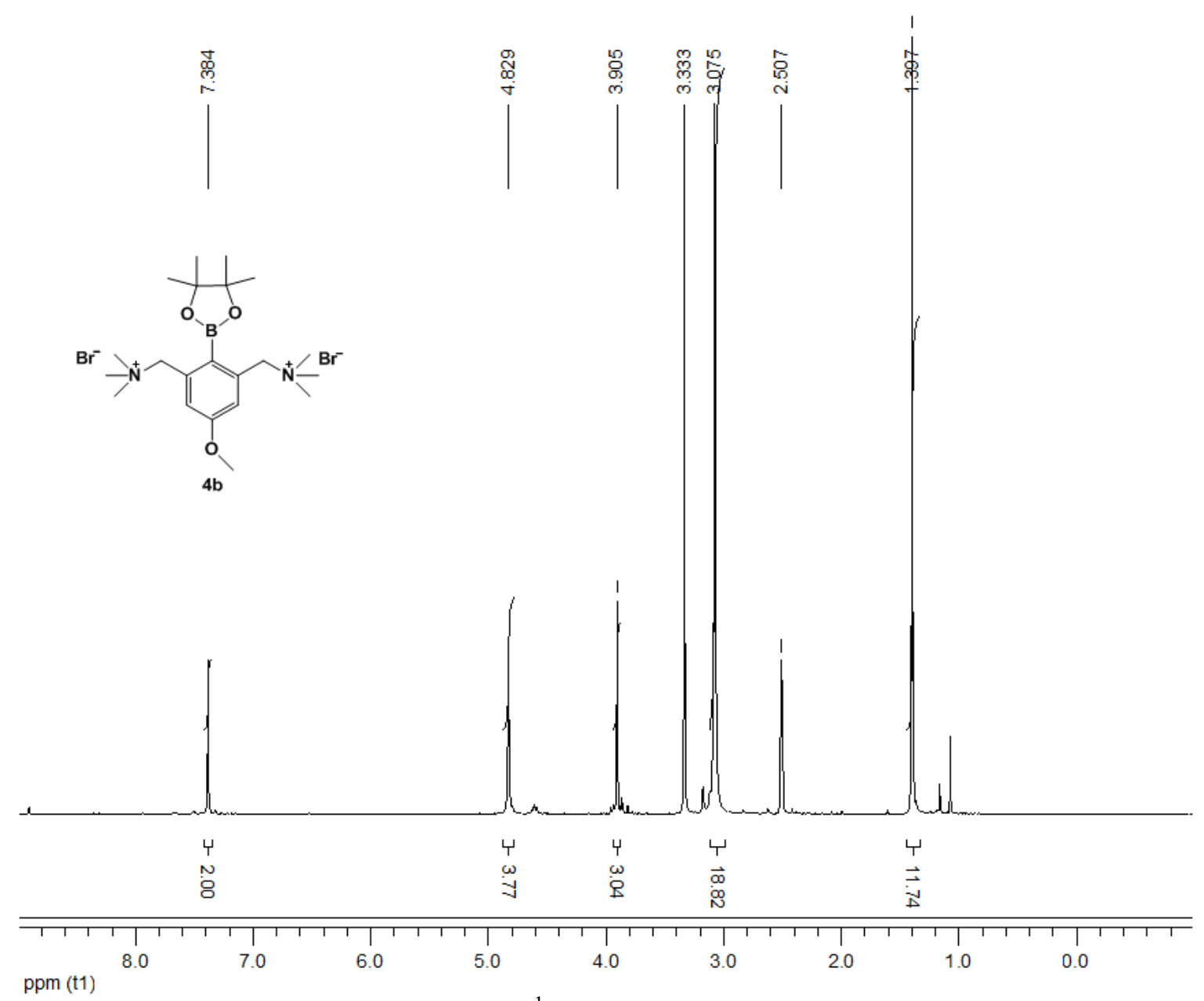

Figure S34. ${ }^{1} \mathrm{H}$ NMR spectra of $\mathbf{4 b}$. 


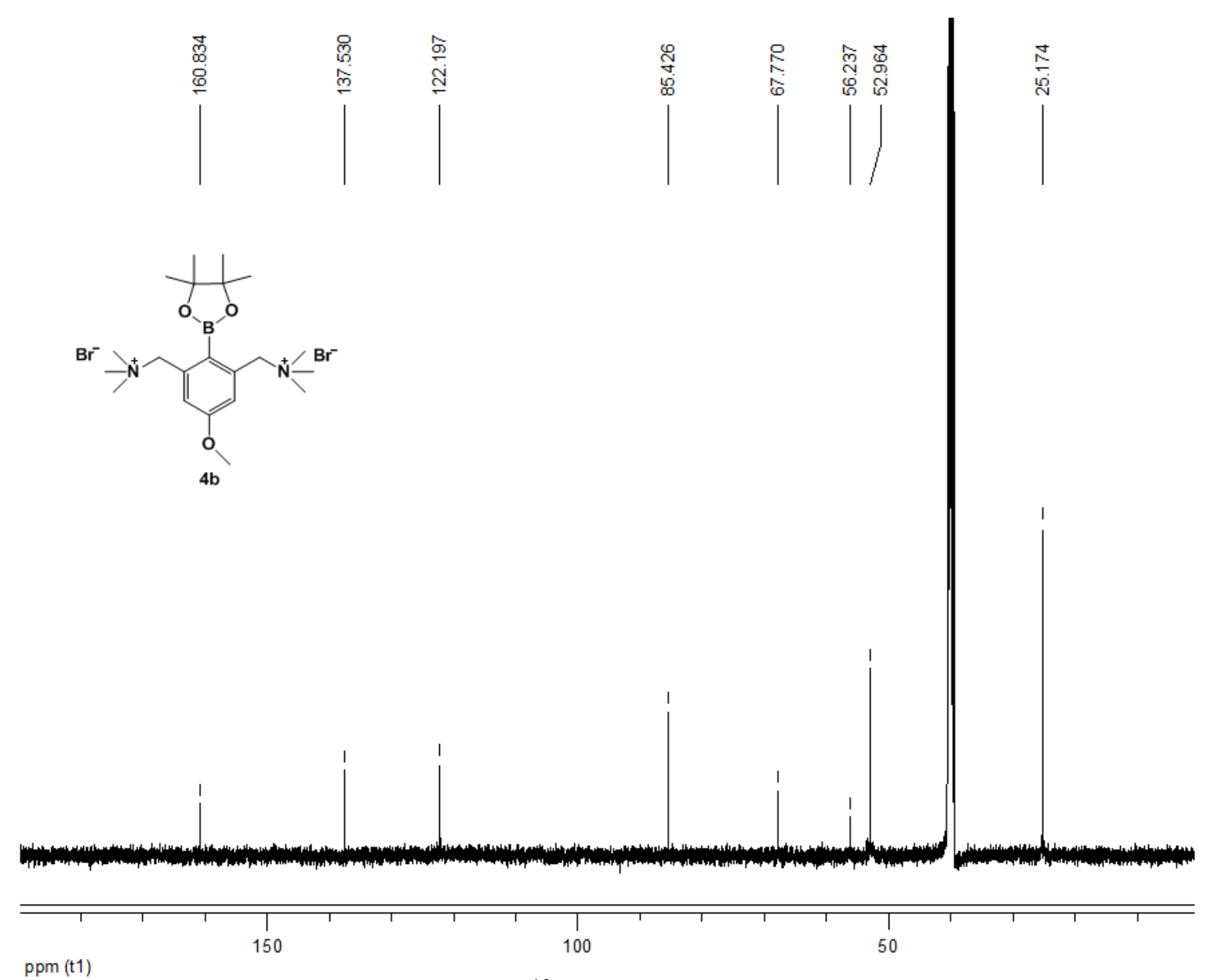

Figure S35. ${ }^{13} \mathrm{C}$ NMR spectra of $\mathbf{4 b}$. 


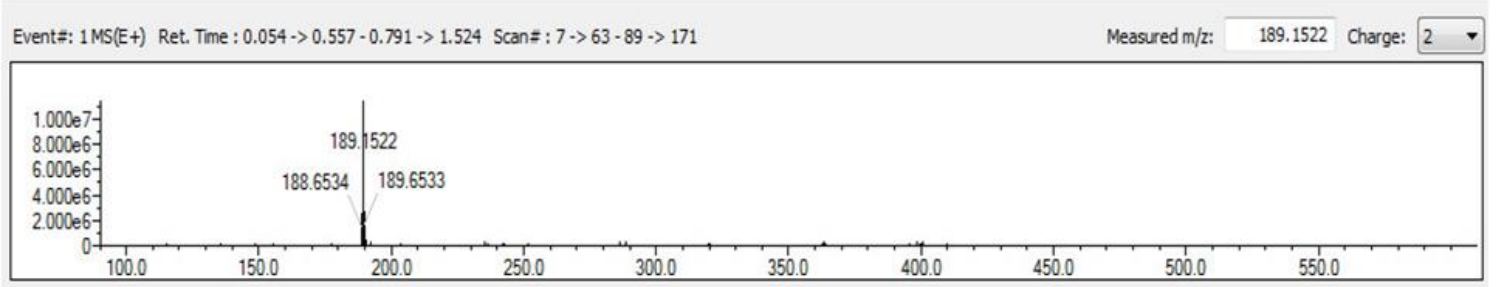

Measured region for $189.1522 \mathrm{~m} / \mathrm{z}$

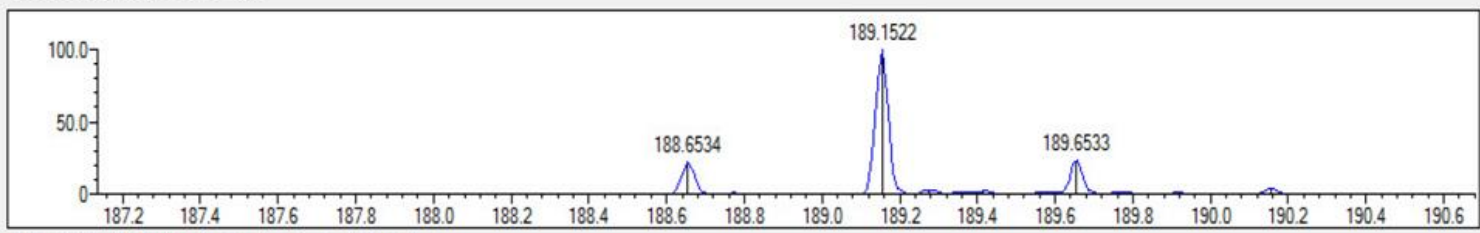

C21 H39 N2 O3 B [M] 2+ : Predicted region for $189.1523 \mathrm{~m} / 2$

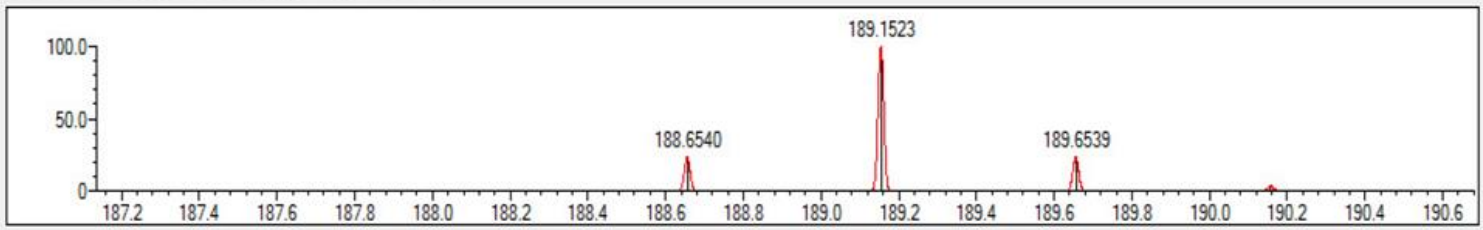

\begin{tabular}{|c|c|c|c|c|c|c|c|c|c|}
\hline Rank & Score & Formula (M) & Ion & Meas. $m / z$ & Pred. m/z & $\operatorname{Diff}(m D a)$ & Diff (ppm) & Iso Score & DBE \\
\hline 1 & 95.20 & $\mathrm{C} 21 \mathrm{H} 39 \mathrm{~N} 2 \mathrm{O} 3 \mathrm{~B}$ & {$[M] 2+$} & 189.1522 & 189.1523 & -0.1 & -0.53 & 95.20 & 4.0 \\
\hline 2 & 87.93 & $\mathrm{C} 19 \mathrm{H} 37 \mathrm{~N} 5 \mathrm{O} 2 \mathrm{~B}$ & {$[M] 2+$} & 189.1522 & 189.1516 & 0.6 & 3.17 & 92.98 & 4.5 \\
\hline 3 & 87.85 & $\mathrm{C} 15 \mathrm{H} 38 \mathrm{~N} 8 \mathrm{O} 3$ & {$[M] 2+$} & 189.1522 & 189.1528 & -0.6 & -3.17 & 92.89 & 1.0 \\
\hline 4 & 57.58 & $\mathrm{C} 14 \mathrm{H} 38 \mathrm{~N} 5 \mathrm{O} 5 \mathrm{~B} 2$ & {$[M] 2+$} & 189.1522 & 189.1527 & -0.5 & -2.64 & 60.04 & -0.5 \\
\hline 5 & 50.00 & $\mathrm{C} 19 \mathrm{H} 33 \mathrm{~N} 6 \mathrm{~B} 3$ & {$[M] 2+$} & 189.1522 & 189.1522 & 0.0 & 0.00 & 50.00 & 8.0 \\
\hline
\end{tabular}

Figure S36. IT-TOF-MS (ESI) of $\mathbf{4 b .}$ 


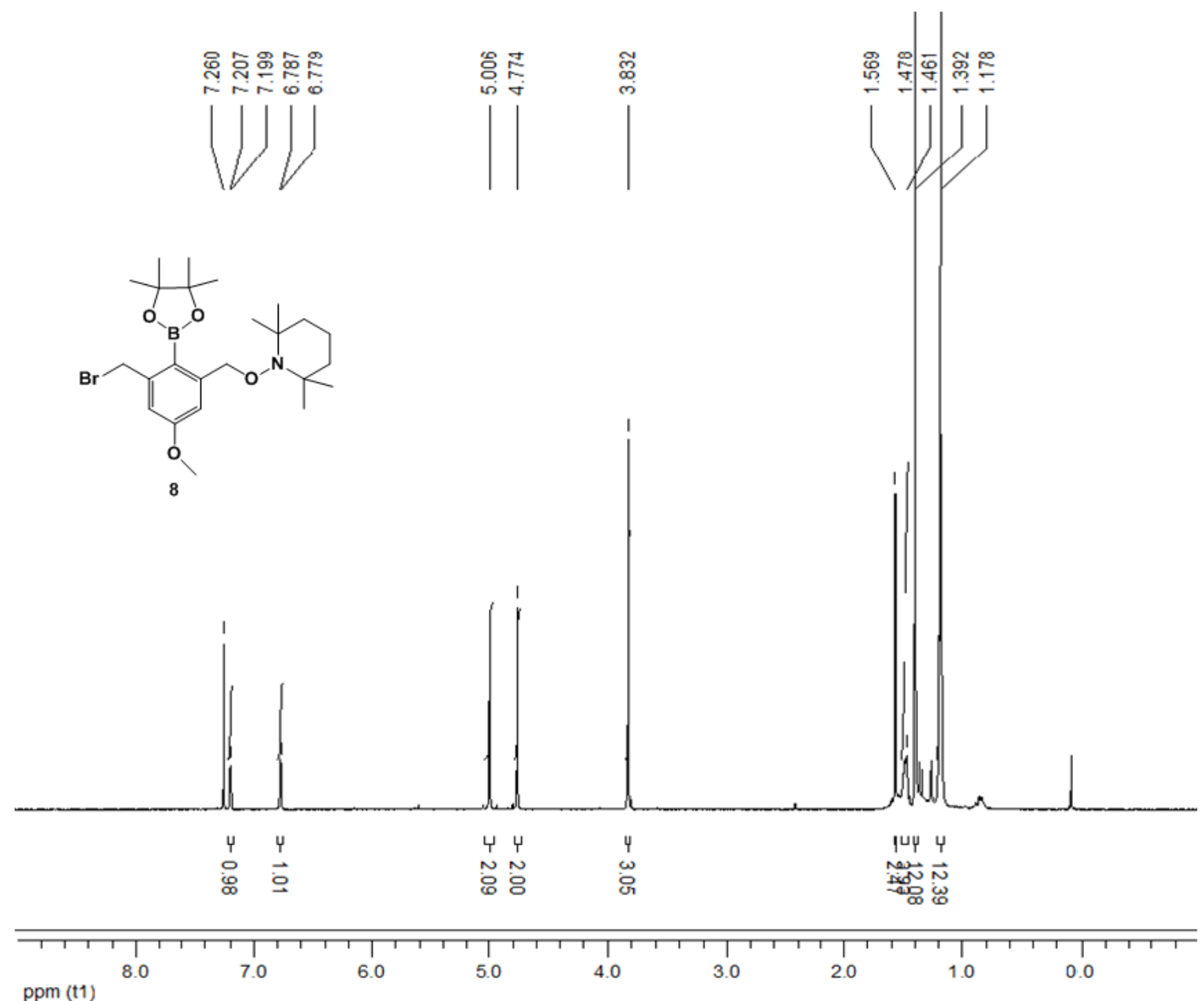

Figure S37. ${ }^{1}$ H NMR spectra of 8 . 


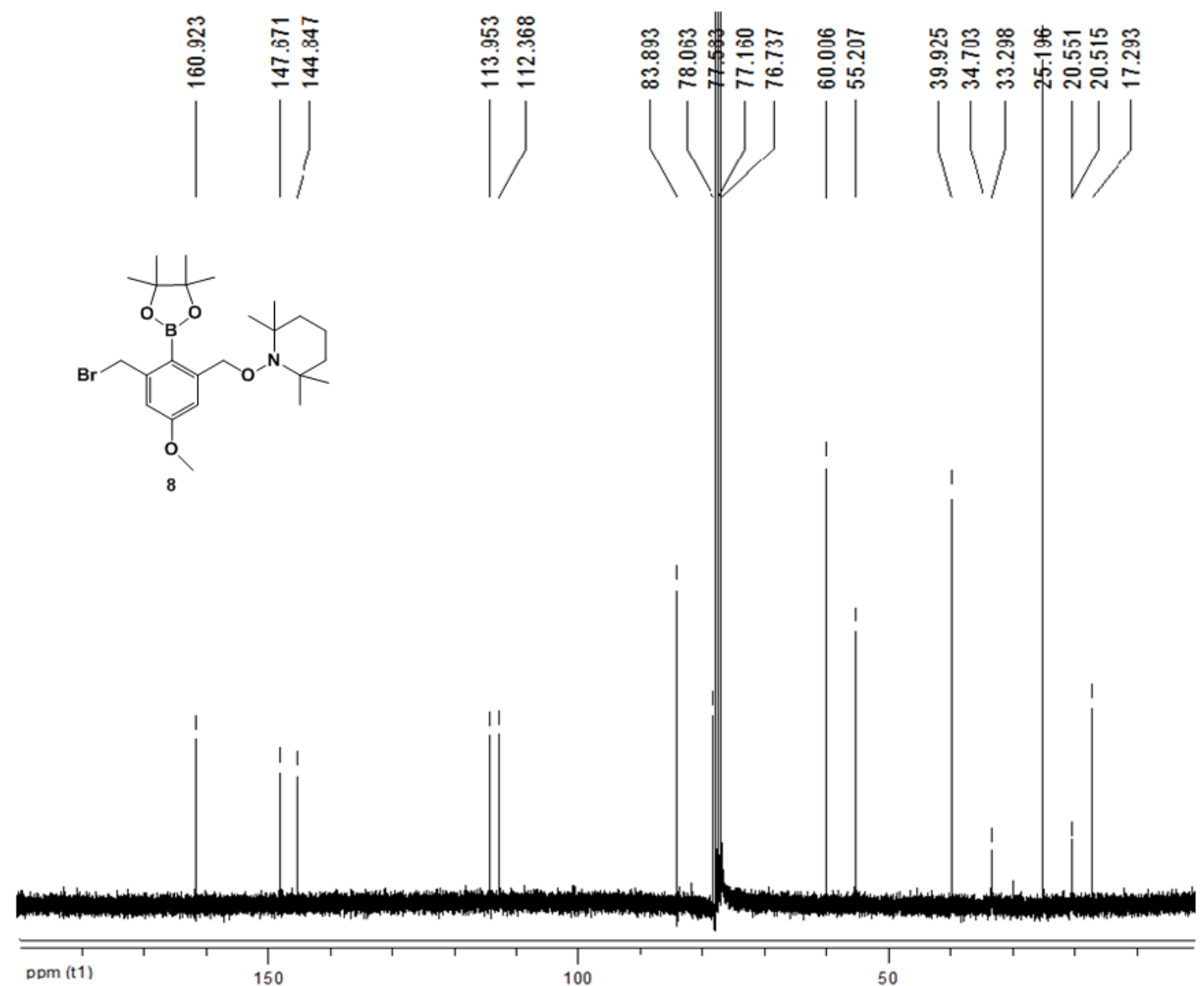

Figure S38. ${ }^{13} \mathrm{C}$ NMR spectra of 8 . 

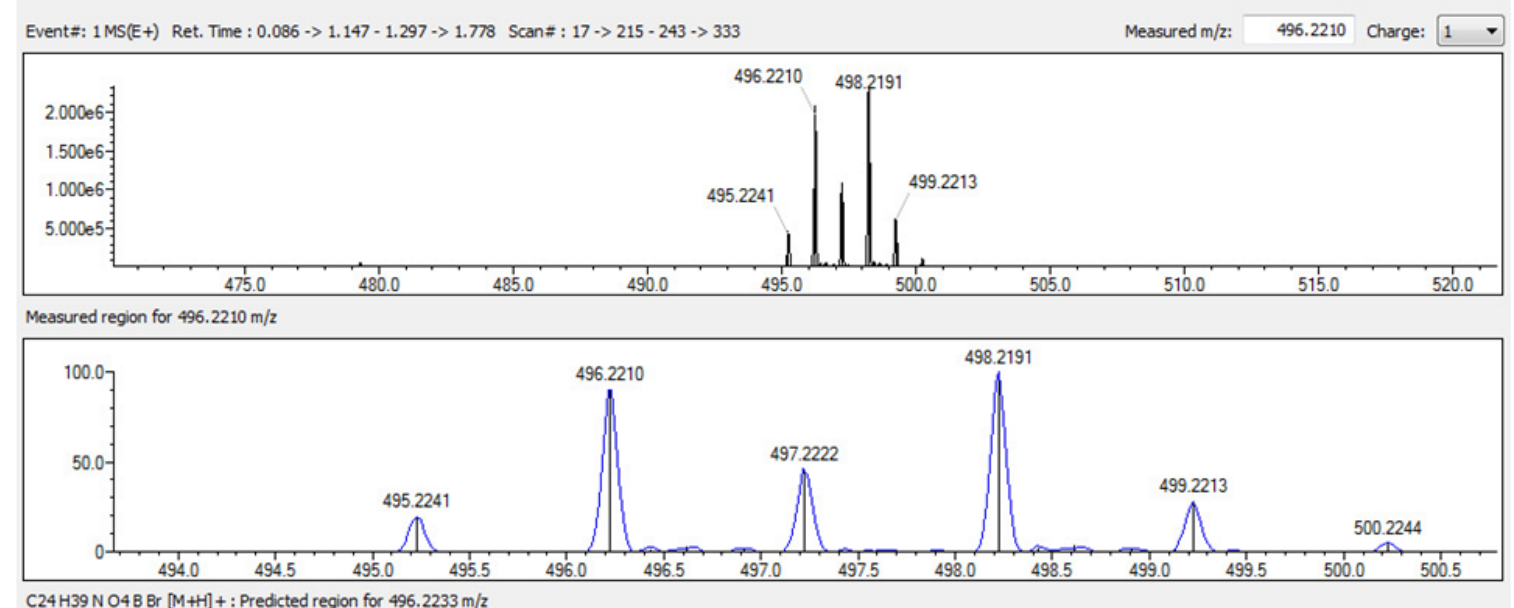

C24 H39 N 04 B Br [MH H] + : Predicted region for $496.2233 \mathrm{~m} / 2$

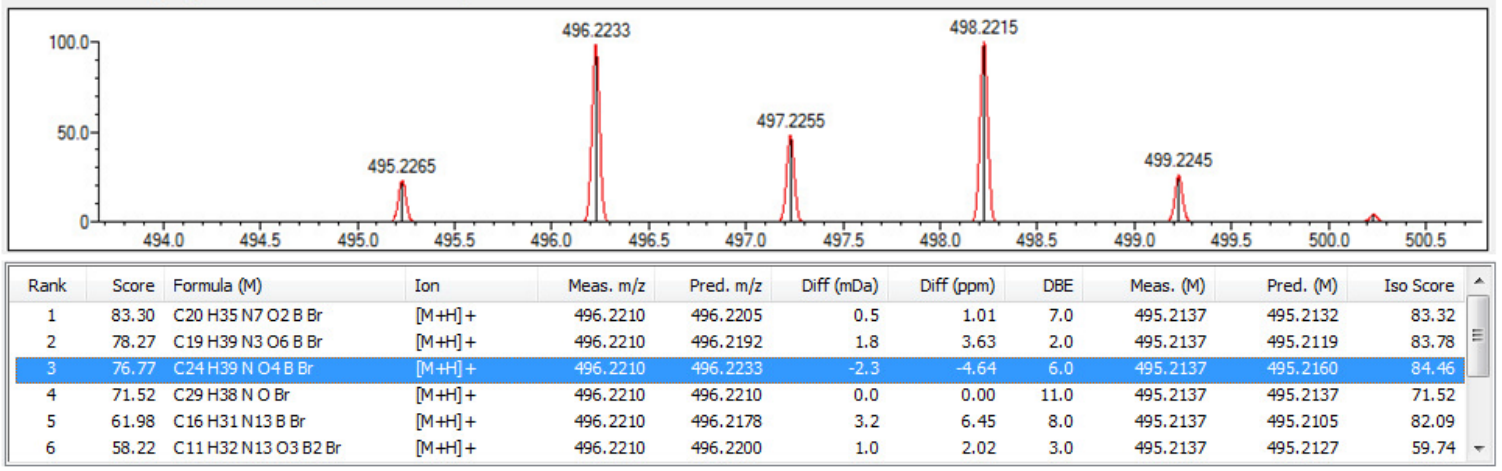

Figure S39. IT-TOF-MS (ESI) of 8. 